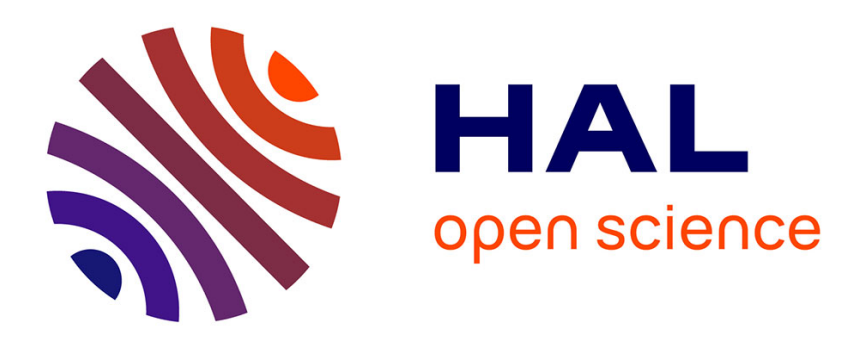

\title{
Voluntary adoption of IFRS: A study of determinants for UK unlisted firms
}

Paul André, Peter Walton, Dan Yang

\section{To cite this version:}

Paul André, Peter Walton, Dan Yang. Voluntary adoption of IFRS: A study of determinants for UK unlisted firms. Comptabilités et Innovation, May 2012, France. pp.cd-rom. hal-00935013

\section{HAL Id: hal-00935013 https://hal.science/hal-00935013}

Submitted on 22 Jan 2014

HAL is a multi-disciplinary open access archive for the deposit and dissemination of scientific research documents, whether they are published or not. The documents may come from teaching and research institutions in France or abroad, or from public or private research centers.
L'archive ouverte pluridisciplinaire HAL, est destinée au dépôt et à la diffusion de documents scientifiques de niveau recherche, publiés ou non, émanant des établissements d'enseignement et de recherche français ou étrangers, des laboratoires publics ou privés. 


\title{
ISSEC
}

BUSINESS SCHOOL

ESSEC KPMG

FINANCIAL REPORTING CENTRE

\section{Voluntary adoption of IFRS: A study of determinants for UK unlisted firms}

\author{
Paul André*, Peter Walton ${ }^{\dagger}$ and Dan Yang ${ }^{\ddagger}$
}

Current version: January 3, 2012

\footnotetext{
* Professor of Accounting ESSEC Business School, Director ESSEC KPMG Financial Reporting Centre and Corresponding author: andre@essec.edu

${ }^{\dagger}$ Professor of Accounting ESSEC Business School, Director ESSEC KPMG Financial Reporting Centre

${ }^{\ddagger}$ School of Economics and Business Administration, Beijing Normal University \& Research fellow ESSEC KPMG Financial Reporting Centre
} 


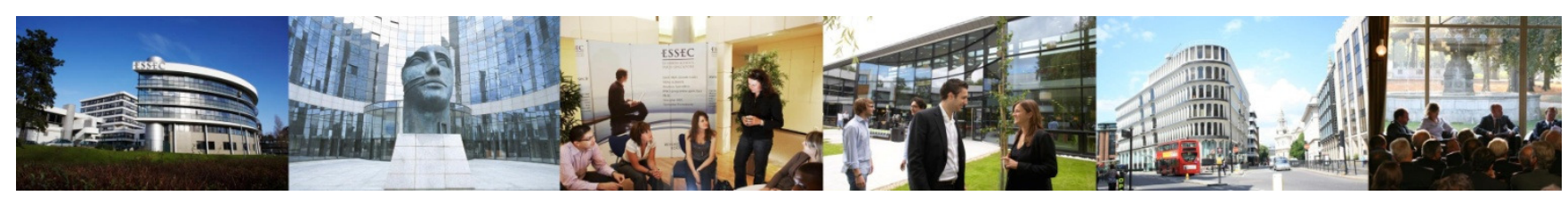

\section{About the ESSEC-KPMG Financial Reporting Centre}

The ESSEC-KPMG Financial Reporting Centre specialises in financial reporting under International Financial reporting Standards (IFRS). Created in 2005, the year in which European listed companies started to use IFRS, the Centre monitors closely the activities of the International Accounting Standards Board and the application of IFRS by European companies.

Our sponsor, KPMG, contributes with financial resources to help the Centre achieve its objectives. KPMG is the leading audit, accounting and advisory firm in France*. The firm provides listed companies and international groups with audit and advisory services and works closely with SMEs, the public sector and the non-profit sector in an audit, accounting and advisory capacity. KPMG S.A. has branches in 217 cities in France and is a member of the KPMG International network which has firms in 150 countries.

*Source "La profession comptable 2010"

The activity of the Centre falls into three inter-related streams activity: IFRS Observatory, Education and Research. The Centre is headed by three permanent faculty members of the ESSEC Accounting and Management Control Department: Peter Walton, Wolfgang Dick and Paul André.

For more information about the Centre, visit: www.essec-kpmg.net

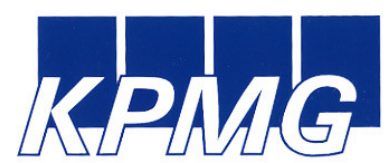




\section{Voluntary adoption of IFRS: A study of determinants for UK unlisted firms}

Abstract:

We examine the determinants of voluntary adoption of IFRS by medium-to-large UK unlisted firms (8417 firms comprising 287 IFRS firms and 8130 non-IFRS firms in 2009). Analysing voluntary adoption allows us to better understand the cost/benefits of choosing a specific set of accounting standards. Using univariate and multivariate analyses, we find that internationality, leverage, firm size and auditor reputation help explain UK unlisted firms' choice of voluntarily selecting IFRS. Other firm characteristics such as profitability, capital intensity, industry, growth, ownership structure, and employee productivity do not appear to play a significant role in the decision. Additionally, we find that newly incorporated firms a higher probability of adopting IFRS. 


\section{INTRODUCTION}

Proponents of International Financial Reporting Standards (IFRS) claim that IFRS increases financial comparability and usefulness of accounting information (FASB 2010; IASB 2010; SEC 2008; Tweedie 2010). Since 2005, all listed companies in the European Union (EU) are required to prepare their consolidated financial statements in accordance with IFRS. Subsequently, they have become mandatory in Australia, Canada, Brazil, Korea and many other countries. They are optional for Japanese listed companies, and Chinese companies use standards that are closely based on IFRS. India is planning a move to IFRS and Japan will consider making their use mandatory next year. The Securities and Exchange Commission (SEC) in the US has supported the development of international standards for many years. The SEC started to permit non-US firms that use IFRS to file financial statements with the SEC without reconciliation to US GAAP since 2007, and the Commission also proposed a roadmap for the potential use of IFRS to file financial reports of US firms in 2008 (SEC 2008). It is planning to decide if it will adopt them, and how to do so as painlessly as possible.

However, the recent effort for convergence of global accounting standards is continually debated. For example, commenting on the SEC's roadmap, Jamal et al. (2010) from the American Accounting Association's Financial Accounting Standards Committee are supportive of the idea of standards competition and argue that a single global set of financial reporting standards is not optimal. Allowing U.S. companies to choose between U.S. GAAP and IFRS can have a higher likelihood of generating high-quality financial reporting (Hail et al. 2010a; Hail et al. 2010b; Jamal et al. 2010). They also indicate that the promise that IFRS adoption will deliver comparability in accounting reports is misleading and insufficient because accounting standards are not the only variable affecting the quality of accounting reports, other variables may derive from the business and financial culture, the accounting and auditing culture, and the legal system (Ball et al. 2000; Schipper 2005; Soderstrom and Sun 2007; Zeff 2007; Leuz and Wysocki 2008; Hail et al. 2010a; Hail et al. 2010b).

Besides the on-going debate among policy makers, academics and users, academic studies measuring the economic consequences of IFRS adoption also reach conflicting results. Some recent studies provide evidence of benefits in the form of improvement in comparability, increased understanding by financial statement users, lower benefits from private information, lower cost of capital and higher liquidity (Wu and Zhang 2010; Barth et al. 2011; Brochet et al. 2011; DeFond et al. 2011). Other studies suggest that a mere switch to a common set of accounting standards does not necessarily bring about the anticipated improvement in earnings comparability and enhanced information quality (Beuselinck et al. 2007; Cascino and Gassen 2010; Kvaal and Nobes 2010; Lang et al. 2010). Thus, the impact of IFRS adoption is a priori not obvious.

Regulators and investors, especially those located in the countries that are applying IFRS and those that are about to, have begun to challenge the widespread adoption of IFRS. They 
wonder whether IFRS go too far or whether all the firms should use IFRS to prepare their financial statements, and whether all the firms benefit from IFRS adoption. For example, interviews by the AFG (French Asset Management Association) and the FFSA (French Federation of Insurance Companies) (2007) indicate that financial statements users point to a significant gap between the ideal of comparability as publicized by IFRS supporters, and the degree to which financial statements prepared in accordance with IFRS are actually comparable. $^{4}$

The SEC's proposal to adopt IFRS has attracted a great deal of comment from US issuers, including the observation that for companies working only in the US domestic market there is no gain from using IFRS (see for example comment letter of 9 August 2011 from Ted Timmermans, Williams Industries). In Europe IFRS were adopted for all listed companies within the EU primarily to support the development of a single financial market (Danjou \& Walton forthcoming). However, this has led subsequently to protests from medium-sized and small companies that there are no benefits for them in using IFRS (e.g. Pascal Imbert, president of MiddleNext, speech 12 October 2011).

This leads to a situation where within one market there appear to be listed companies that believe using IFRS is beneficial to them, and another that believe the opposite. In the policy arena, this implies that the EU decision to have blanket adoption may have been counterproductive for a number of EU listed companies and also that the SEC should consider something other than full adoption. There is no obvious means of identifying which companies in the EU have benefited and which believe they have not. However, an alternative does present itself. In countries where IFRS can be adopted voluntarily by unlisted companies, it may be that examining the characteristics of voluntary adopters may shed light on the policy issue for regulators.

Because voluntary adopters willingly apply IFRS while others do not, it is reasonable to assume that "managers of voluntary adopters view IFRS as their preferred reporting strategy while managers of others do not view it as such" (Drake et al. 2010), and adoption effects of IFRS may vary between voluntary and mandatory adopters (Christensen et al. 2008; Paananen and Lin 2009) ${ }^{5}$. Also voluntary adopters face large adoption/switching costs (Soderstrom and Sun 2007). Given that firms are making rational decisions on the choice of financial reporting standards through weighting benefits and costs, voluntary adopters must have reasons and incentives to incur these adoption/switching costs. Therefore, examining characteristics of firms that voluntarily adopt IFRS is beneficial in providing a profile of firms

\footnotetext{
${ }^{4}$ Information is from: Durocher, S. and Y. Gendron (2011).

${ }^{5}$ Christensen et al. (2008) exploit the unique setting that exists in Germany, and find that earnings management decreases and timely loss recognition increases for voluntary IFRS adopters while no accounting quality improvements are found for firms that resist IFRS until 2005. Similarly, Paananen and Lin (2009) investigate earnings quality for German firms during IAS period (2000-2002), IFRS voluntary period (2003-2004) and IFRS mandatory period (2005-2006), and indicate that accounting quality has not improved but worsened over time.
} 
that perceive benefits from using IFRS. It should also feed into the policy debate by indicating the type of companies which may prefer to use and benefit from a particular set of accounting standards.

This paper is organized as follows. In section 2, a brief review on all the firm characteristics of voluntary IFRS adoption documented in prior studies is provided. Section 3 forms the research motivation of this paper. Section 4 discusses the possible determinants of the decision in voluntarily selecting IFRS, and outlines research hypotheses formulated. Section 5 contains the research model and variables, and describes the research sample and data collection. Section 6 presents the empirical results. Section 7 draws this paper into a conclusion.

\section{LITERATURE REVIEW}

The earliest research regarding why firms comply voluntarily with international accounting standards (IFRS or IAS) comes from Switzerland. The reasons are, first, Switzerland is one of countries that had a high percentage of firms voluntarily choosing IAS in 1990s, second, Swiss GAAP was argued to be much less stringent than international standards for both valuation rules and disclosure requirements, so switching to IAS was likely to be more costly for Swiss firms than for firms from countries with higher reporting standards; third, given the above reason, voluntary adopters in Swiss firms should expect more advantages from IAS adoption (Dumontier and Raffournier 1998; Murphy 1999). The first direct investigation was conducted by Dumontier and Raffournier (1998), who examined eight characteristics of firms with voluntary compliance to IAS in 1994, including listing status, internationality, size, ownership structure, leverage, capital intensity, profitability and auditors' reputation. Due to the absence of prior research, the characteristics were drawn from studies on the determinants of voluntary disclosure, because compliance with IAS would imply considerable additional disclosure (Dumontier and Raffournier 1998). One of the bases for Dumontier and Raffournier's research (1998) is work carried out by Raffournier (1995), who measured whether company size, leverage, profitability, ownership structure, internationality, auditor's size, percentage of fixed assets and industry type, act as the determinants of voluntary financial disclosure by Swiss listed companies. His results indicate that size and internationality play a major role in the disclosure policy of firms, large and internationally diversified companies tending to disclose more information than small purely domestic enterprises (Raffournier 1995). Dumontier and Raffournier (1998) further find that firms which comply with IAS are larger, more internationally diversified, less capital intensive and have a more diffuse ownership, through univariate test and Logistic regression. The results are consistent with that in Raffournier's paper (1995), and suggest that political costs and pressures from outside markets play a major role in the decision to apply IAS. Following Dumontier and Raffournier (1998), Murphy (1999) also examines firm characteristics of Swiss companies that use IAS to prepare financial reports in 1995 , adding a market value variable but not finding this significant; she indicates that the only difference between 
voluntary adopters and non-adopters are the level of foreign activity, as measured by the percentage of foreign sales and the percentage of foreign stock exchange listings, confirming that companies with higher levels of foreign activity perceive a benefit from using international standards.

Studies examining firm characteristics of voluntary adoption of international standards then cover firms across different countries. El-Gazzar et al. (1999) investigate multinational firms' compliance with IAS from 1995 to 1997, and find that besides listing status, internationality and leverage, geographical and trade blocks membership (e.g., EU) also significantly relates to voluntary adoption of IAS. The findings suggest that firms are motivated to voluntarily adopt IAS so as to enhance their exposure to foreign markets, to improve customer recognition, to secure foreign capital, and reduce political costs of doing business abroad; also accounting disclosure choices are affected by the harmonizing and encompassing effects of market forces and global culture (El-Gazzar et al. 1999). Although El-Gazzar et al. (1999) indicate that firms from EU countries are more likely to choose IAS, Street and Gray (2002) find a significant negative association of the extent of adherence to IAS with being domiciled in EU countries. Street and Gray (2002) do not investigate why and which firms comply voluntarily with international accounting standards, but assess the extent of compliance and factors associated with compliance for firms that have already applied IAS. Based on prior research, Street and Gray (2002) examine the impact of 11 firm characteristics (including listing status, company size, profitability, industry, the manner in which companies refer to IAS in the accounting policies footnote, type of auditor, type of accounting standards used by the company as stated in the audit report, type of audit standards, country, multi-nationality and size of the home stock market) on the extent of compliance with IAS in 1998 annual reports. They find that listing status, being audited by a Big $5+2$ firm, the type of reference to IAS, and country of domicile significantly associated with the extent of non-compliance, especially in respect of IAS disclosures. Specially, incentives for adhering to IAS are clearly linked to being listed outside the home region; being audited by Big $5+2$ firms is important for promoting compliance; national barriers to IAS compliance are evident in EU countries, especially in France and Germany; and interestingly, there are higher levels of compliance for companies based in Switzerland and China, possibly because of the big differences between IAS and low-required local GAAP.

Some studies examine why voluntary adoption of non-local GAAP (IAS or U.S. GAAP) took place for firms in non-US countries. Tarca (2004) indicates that choice of US GAAP or IAS relates to firm-specific characteristics which vary according to a firm's country of origin. Using a sample of listed firms from the UK, France, Germany, Japan and Australia in 1999 and 2000, she finds that firms that are larger, have more foreign revenue and are listed on one or more foreign stock exchanges are likely to adopt international standards. Choices of US GAAP and IAS also differ with firm attributes. US GAAP was the predominant choice, but IAS were used by many firms in Germany and some in Japan. Firms traded in the US regulated markets (NYSE and NASDAQ) prefer to select US GAAP, while companies listed in 
the OTC market are more likely to use IAS. Also, the study reveals that the extent of firm attributes and the way standards are used vary between each of the five countries. For example, firms from Germany and Japan are more inclined to adopt, while firms from the UK, France and Australia are more likely to make supplementary use of non-local accounting standards. In a study similar to Tarca (2004), Cuijpers and Buijink (2005) examined the determinants of voluntary adoption of non-local GAAP for EU firms. First, they indicate that the percentage of adoption of non-local GAAP by EU firms in 1999 was relatively low, suggesting that only a minority of EU listed firms expect to benefit from non-local GAAP adoption. Then they find that characteristics that discriminate voluntary adopters and nonadopters are that voluntary adopters are of larger size, are more likely to be listed on a US exchange or the EASDAQ exchange, have more geographically dispersed operations, and are more likely to be domiciled in countries with lower quality financial reporting and in countries where IAS is explicitly allowed as an alternative to local GAAP. They also found that corporate governance attributes do not show a significant association with non-local GAAP adoption.

They also examine whether firms using IAS or US GAAP benefit from a lower level of information asymmetry. The findings reveal a positive effect on analyst following, but negative evidence of a lower cost of capital, and uncertainty among analysts and investors (forecast accuracy and stock return volatility) seem to be higher for firms using IAS or US GAAP. Two possible reasons for the small benefits are that (i) analysts and investors may need time to learn to understand the changes in financial reporting, and (ii) accounting standards are not the only variable determining accounting quality: management's reporting incentives also play an important role (Ball et al. 2003). Wu and Zhang (2009) additionally examine whether performance evaluation demands, such as closely held shares and labour productivity, are related to the IFRS/ US GAAP adoption decision by non-US firms. They test the relation using a large sample of Continental European firms from 1988 to 2004, and find a significant positive association, firms that have less closely held shares and lower labour productivity have a higher probability of IFRS/ US GAAP adoption.

Recognizing the role of country specific factors and listing status in determining voluntary adoption of international financial reporting standards, more recent studies examine the determinants of firms within a specific country or adoption/switching by private firms. For example, Gassen and Sellhorn (2006) investigate firm characteristics of voluntary IFRS adoption by German firms during the period from 1998 to 2004. They find that younger, larger German firms, listed in the US, with a higher proportion of foreign sales and more dispersed ownership tend to adopt IFRS, so company size, international orientation, ownership dispersion, and recent IPO activity are important drivers in Germany. They then further examine the consequences of voluntary IFRS adoption by testing earnings quality and the level of information asymmetry for voluntary adopters and German non-adopters. Their findings suggest that the earnings of IFRS firms are of higher quality, with more persistent, 
less predictable and more conditionally conservative earnings, and IFRS adopters experience lower levels of information asymmetry.

Guenther et al. (2009) focus on the impact of ownership structures on voluntary IFRS adoption in Germany. Concentrated ownership structures in Germany facilitate communication between firms and investors via private information channels, thus controlling shareholders may believe that any benefit arising from IFRS adoption would be less than the cost of implementation and transition. German firms heavily rely on bank debt and internal financing, and banks could be supposed to have superior access to company information (either through debt contracts or through their role as insiders) and a particular interest to maintain a creditor-orientated accounting system. Furthermore, foreign owners are expected to prefer IFRS since the adoption of an internationally accepted set of accounting standards could reduce information processing costs and hence help reduce home bias. Analyzing 543 German firms in the period from 1998 to 2008, the authors find negative influence of ownership concentration and bank ownership on voluntary IFRS adoption in Germany. Interestingly, foreign ownership has been found as a factor that delayed IFRS adoption. That could be explained by the fact that these foreign owners hold rather large stakes in German firms and might therefore deem private communication channels as being more efficient.

Francis et al. (2008) investigate small and medium-sized private firms, and claim that both firm-level incentives that decrease information asymmetry and country-level institutional factors that shape the reporting environment influence the IAS adoption decisions. Additionally, they also indicate that firm factors appear to play a relatively more important role than country-level factors in more developed countries, while in less developed countries, country factors dominate firm factors in explaining IAS adoptions, although firm incentives are still important.

Bassemir (2011) explores why German private firms choose to comply with IFRS. The author argues that in terms of ownership structure, the key difference across private firms arises rather from the type of the controlling owners than from the degree of ownership concentration. He expects that incentives for voluntary IFRS adoption by private equity backed firms may arise, because for one reason, information asymmetries between managers and private equity sponsors create a demand for high quality financial reporting, for the other reason, private equity investors which are often from an Anglo-Saxon background are likely to prefer accounting figures based on IFRS over local GAAP (p. 14). Also he states that the legal form of a private firm may act as a determinant role and incorporated entities may be more likely to adopt IFRS. Then through empirical tests on 3150 German private firms through 1998-2009, the author finds supportive evidence that private firms that decide to implement IFRS are more apt to be registered as Stock Corporation and characterized by private equity involvement. As far as financing goes, the author argues that traditionally German private firms are financed by bank loans and they 
establish close ties on a private basis with their lending banks which in turn should reduce their incentives to provide higher quality public reporting (p. 10). Thus the association between leverage and IFRS adoption is a priori not clear. Results reveal that private firms are more likely to implement IFRS when they are more leveraged.

Table 1 summarizes and lists all the firm characteristics of voluntary adopters of IFRS (or IAS) examined in the literature, statistical results and relevant studies that confirm the characteristics. The ordering of the firm characteristics in table 1 indicates the frequency of examination (decreasing from internationally oriented to geographical and trade blocks membership). For example, almost all the relevant studies investigate the internationallyoriented factor and most of them find consistent results that firms which comply with IAS tend to be more internationally diversified; while for other firm characteristics, mixed findings are reached across different samples.

$<$ Table 1 $>$

\section{RESEARCH MOTIVATION}

The current literature provides some evidence regarding the determinants of voluntary IFRS adoption, but also leaves scope for a great deal more research to complement the recent studies. First, most of previous academic research on financial reporting choices focuses on listed firms, information on unlisted firms being more difficult to gather. Thus, it is not surprising that empirical evidence on the determinants of voluntary IFRS adoption by unlisted firms is scarce, and the only existing relevant studies are conducted by Francis et al. (2008) and Bassemir (2011).

Research on accounting practices of unlisted firms is of potential significance to regulators: more than 99 percent of firms in Europe and in the US are private and unlisted (Bassemir 2011, page 4). IFRS adoption has advanced rapidly since 2005 and use of IFRS is now required or permitted for listed firms in more than 100 countries $^{6}$. Regulators in countries that have not yet adopted IFRS need to be able to assess where adoption is most beneficial, and where IFRS have already been adopted, such as the EU, regulators need to know whether any adjustment of this policy is necessary.

Second, previous academic studies are subject to several limitations. Francis et al. (2008) conduct an investigation on 3722 small and medium-sized private firms from 56 countries in 1999, and claim that both firm-level incentives aiming to decrease information asymmetry and country-level institutional factors that shape reporting environment influence the IAS adoption decision. However, the World Bank Survey they use does not refer to "IAS adoption" and its phrase "use international accounting standards" is vague and the sample

\footnotetext{
${ }^{6}$ Information is from Deloitte's (2011) IAS Plus website: http://www.iasplus.com/index.htm
} 
includes countries where private firms are required to adopt IFRS and countries where IFRS adoption is not permitted for private firms at all (Nobes 2010).

Bassemir (2011) also investigates why private firms adopt IFRS. The author focuses on the specific institutional features of the German setting and models the choice between German GAAP and IFRS for the consolidated financial statements of 3,150 private, non-financial firms (357 IFRS firms versus 2,793 non-IFRS firms) during the period 1998 to 2009. However, the results from German data are difficult to extend to firms from other countries due to different financial reporting environment in each country. The other important thing is that in Europe, unlisted firms are a much wider category than private firms (Nobes 2010), for example, PLCs in the UK, AGs in Germany or SAs in France, are public firms but not quoted. Thus, the results from private firms can not extend to unlisted firms as well.

This paper complements previous research by contributing to the literature investigating the determinants of voluntary IFRS adoption, looking more specifically to UK unlisted firms. The aim is to further understand the cost/benefit issues surrounding the decision to adopt a specific set of standards.

\section{RESEARCH HYPOTHESIS}

The hypotheses that we set out to test are as follows:

\section{INTERNATIONALITY}

Generally, firms operating internationally are more likely 1) to have a much more heterogeneous group of stakeholders; 2) to need to report to various international constituents; 3) to need to improve international customer recognition; and 4) to prefer reducing restatement costs and increasing reporting transparency. This applies to unlisted firms as well. Unlisted firms with foreign subsidiaries are often financed with local external capital and regulated by local market, so compliance with IFRS may lead to financial information more readable and realize cost savings. It is reasonable that more international orientation should be associated with more benefits from using IFRS than operations only on a national level. Previous research for listed firms (Dumontier and Raffournier 1998; Murphy 1999; El-Gazzar et al. 1999; Tarca 2004; Cuijpers and Buijink 2005; Gassen and Sellhorn 2006; Wu and Zhang 2009) supports that internationality acts as an important driver in accounting standards choice and reveals positive results.

H1: Unlisted firms with more international orientation are more likely to comply with IFRS.

\section{CAPITAL STRUCTURE/ LEVERAGE}

Prior research on voluntary IFRS adoption by listed firms presents mixed arguments and evidence regarding the role of leverage in affecting firms' international accounting standards choices. For example, Dumontier and Raffournier (1998) argue that the more levered the 
firm, the higher demand of an efficient monitoring of agency relationships between shareholders and creditors, because adoption of IAS may help facilitate the monitoring role of financial statements through making the smoothing behaviours more difficult. Other researchers (e.g., El-Gazzar et al. 1999, Murphy 1999, Tarca 2004) hold that leverage can act as a proxy to capture the firm's dependence on equity capital; firms with lower leverage are relatively more dependent on equity capital, and are thus more inclined to be subject to shareholders' demands for more disclosed information so as to reduce information asymmetry.

In this paper, we expect that for unlisted firms, higher level of leverage is associated with more voluntary information disclosure, because unlisted firms may prefer easier access to international creditors to receive better financing terms through using IFRS and this may become more beneficial as leverage level increases.

H2: Unlisted firms with higher leverage level are more likely to comply with IFRS.

\section{SIZE}

Firm size is expected to be one factor in determining firm's accounting standards. Firstly, higher level of information disclosure is less costly for larger firms since these are expected to produce this information for internal purposes (Dumontier and Raffournier 1998). Secondly, besides information production costs, political costs (caused by public exposure) and agency costs (caused by more dispersed ownership) may also drive larger firms to voluntarily make more disclosures (Cuijpers and Buijink 2005, page 498). Thirdly, larger firms may have the financial resources permitted to implement a new set of financial reporting standards. And fourth, larger firms are more likely to be involved in more international activities. Most of prior research for listed firms in different countries (e.g. Dumontier and Raffournier 1998; Tarca 2004; Cuijpers and Buijink 2005; Gassen and Sellhorn 2006) find positive evidence that the propensity to adopt/comply with IFRS increases with corporate size.

H3: Larger unlisted firms are more likely to comply with IFRS.

\section{PROFITABILITY}

Similar to leverage level, the association between profitability and voluntary IFRS adoption is a priori not clear. Since compliance with IFRS makes earnings management more difficult, firms choosing to use IFRS may be providing a signal of superior performance, and so it could be expected that the propensity to adopt IFRS increases with profitability. However, IFRS adoption is typically a long-term choice in financial information disclosure policy which may be taken regardless of a firm's profitability. Prior studies (Dumontier and Raffournier 1998; Wu and Zhang 2009; Bassemir 2011) all fail to document significant relation between profitability and voluntary adoption/compliance with IFRS; therefore, in this paper, we do not predict how firm profitability affects firm's financial practices choice. 
H4: Firm profitability does not affect the likelihood of voluntary IFRS adoption by unlisted firms.

\section{CAPITAL INTENSITY}

In Dumontier and Raffournier's (1998) paper, the authors use the proportion of fixed assets to total assets as a proxy for capital intensity. When the firm's finance is invested mainly in fixed assets, the need for monitoring should be less than for those with a high proportion of current assets; accordingly, compliance with IFRS should be more necessary for firms in the latter category. Based on this argument, in this paper we predict a negative association between capital intensity and voluntary IFRS adoption by unlisted firms.

H5: Unlisted firms with less capital intensity are more likely to comply with IFRS.

\section{INDUSTRY}

Accounting practices choice depends on, at least partly, management incentives, and accounting choices driven by management incentives tend to cluster within industry (Bowen et al. 1999). The level of voluntary disclosure may vary between industries due to industryspecific accounting regulation or competitive pressures. These factors may as well cause industry differences in the costs and benefits of complying with IFRS. In this paper, we expect that voluntary IFRS adoption by unlisted firms may vary among different industries.

H6: The likelihood of voluntary IFRS adoption by unlisted firms is affected by industry.

\section{GROWTH}

In previous research on accounting standards choice by private firms (Francis et al. 2008; Bassemir 2011), growth has been suggested as one determinant in the decision process. Firms with expected future growth opportunities are more likely to be seeking external financing to fund current and future profitable projects, and in order to provide a signal of high quality accounting information to external capital providers are more motivated to adopt IFRS. We also expect a positive association between voluntary IFRS adoption and firm's growth.

H7: Unlisted firms with higher growth level are more likely to comply with IFRS.

\section{OWNERSHIP STRUCTURE}

Ownership structure for listed firms has been discussed and recognized as a factor in determining firms' choice of accounting practices (Dumontier and Raffournier 1998; Cuijpers and Buijink 2005; Gassen and Sellhorn 2006; Wu and Zhang 2009; Guenther et al. 2009). More closely held firms and those where there is little distance between owners and managers may face quite different costs/benefits of changing accounting regimes. Unfortunately, the Orbis database does not allow for a detailed breakdown of ownership^. 
We only have some information on their legal forms: public (not quoted) firms, private limited firms, and other firms (e.g. limited liability partnership). We control for the legal form without having any precise directional hypothesis.

H8: Legal form (Public (not quoted) firms, private limited firms and other) does not impact the likelihood to voluntarily adopt IFRS than other firms.

\section{EMPLOYEE PRODUCTIVITY}

Wu and Zhang (2009) argue that the demand for performance evaluation is related to the IFRS/US GAAP adoption decision for non-US firms. Firms with lower labour productivity may face a greater demand for informative measures of firm performance in order to facilitate internal performance evaluation, therefore a higher probability of IFRS/ US GAAP adoption. Given this argument and empirical evidence, we expect that, employee productivity may affect a firm's decision on the choice of accounting standards. So far no investigation has been done on this issue for unlisted firms.

H9: Unlisted firms with lower employee productivity are more likely to comply with IFRS.

\section{AUDITORS' REPUTATION}

The selection of auditors is expected to be related with firm's adoption of IFRS. On the one hand, once firms voluntarily use IFRS, the credibility of their financial information can be enhanced by having these statements audited by large audit firms with good reputation (Dumontier and Raffournier 1998). Therefore, the selection of auditors may be a consequence of compliance with IFRS. On the other hand, large and international audit firms are more likely to encourage their clients to use IFRS, as the large audit forms have a comparative advantage in this area. Given this argument, the selection of auditors may also be a cause of adopting IFRS. In this paper, we predict that the association between auditors' reputation and voluntary IFRS adoption still applies to unlisted firms and unlisted firms audited by a Big 4 firm are more likely to choose IFRS.

H10: Unlisted firms employing a Big 4 firm as external auditors are more likely to comply with IFRS.

\section{RESEARCH DESIGN}

This section reviews the issues addressed in the design of the research.

\subsection{Research sample and data collection}

The availability and appropriateness of the research sample has been recognized as a major obstacle when investigating the voluntary choice of a comprehensive basis of accounting by 
unlisted firms (Nobes 2010; Bassemir 2011). We select our sample and collect relevant financial data mainly based on the Orbis database. The Orbis database, with claims to have information on all the firms in the world, is provided by Bureau van Dijk Company, which also operates Amadeus database used in much previous research on private firms (e.g. Coppens and Peek 2005; Peek et al. 2010).

The selection criteria applied in identifying the sample for this research are: 1) UK active and unlisted firms; 2) firms preparing financial statements in conformity with IFRS at the end of $2009^{7}$; 3) firms that are large or medium-sized according to the criteria of the Fourth EU Company Law Directive: to be considered as a large or medium-sized firm, the $4^{\text {th }} \mathrm{EU}$ Directive requires that the firm should exceed two or more of the following lower bounds, which are balance sheet total of $€ 2.5$ million, net turnover of $€ 5$ million $^{8}$, and number of employees of 50.4) Unlike other research studies on private firms, we include financial firms in the analyses of unlisted firms. In the EU, there are three different versions of the $4^{\text {th }} \mathrm{EU}$ Directive that contain requirements on several presentation and policy issues: the Directives for banks (1986) and insurance firms (1991) are derived from the $4^{\text {th }}$ company law Directive on the annual accounts of certain types of companies of 1978 (Kvaal and Nobes 2010, page 176). Given these reasons, banks and other financial firms are usually excluded in many prior empirical studies, thus the financial firms are under-examined. In our analyses, financial unlisted firms are included but will be treated separately for the above reasons. 5) We also include subsidiaries in this research. Again, in prior research, firms that are subsidiaries are often excluded, because investment, financing, and operating decisions in such entities are likely to be influenced by their parent companies, which could bias the results if they are included. We therefore chose only subsidiaries whose parent companies are public authority/state/government, families, or private holdings. Based on above selection criteria, we found a total of 287 firms using IFRS, including both independent firms and certain subsidiaries.

Similarly, we also choose the control sample using firms which are: 1) UK active and unlisted firms; 2) firms not using IFRS at the end of 2009; 3) large or medium-sized firms according to the criteria of the Fourth EU Company Law Directive; 4) firms from all industries; and 5) independent firms and subsidiaries whose parent companies are public authority/ state/ government, or families, or other types of holding firms. We arrived at a control sample of 8130 firms.

\footnotetext{
${ }^{7}$ It is important to note that Orbis only allows a search on current accounting practice (i.e. some 2010, some 2011 when we searched initially). We then downloaded the historical variable 'accounting practice in fiscal 2009'). The database indicated a number of firms currently using IFRS where using Local GAAP in 2009. For these firms, we further check actual reports from the Companies House, by downloading their 2009 financial reports and manually reviewing the accounting practices they use. We found that 111 firms labeled as using Local GAAP by Orbis in 2009 actually were using IFRS.

${ }^{8}$ If the financial statements are denominated in local currency, the statements are translated at the exchange rate prevailing at the fiscal year end date.
} 
Overall, these selection criteria result in a full sample of 8417 firms comprising 287 IFRS firms and 8130 non-IFRS firms. As seen in Table 2, the percentage of the UK unlisted firms choosing IFRS in 2009 is quite small, only 3.41 percent (2.88 percent for non-financial firms and 7.75 percent for financial firms).

\section{$<$ Table 2>}

\subsection{Research model and variables}

We use univariate analyses and logistic regression to test the hypothesized relationship of firm characteristics and voluntary IFRS adoption. Logistic regression is an appropriate approach where disproportionate sampling from two populations occurs (Maddala, 1991). In logistic regression, the coefficients of the explanatory variables are unaffected by the unequal sampling rates from the two groups (Palepu 1986). Logistic regression has been generally applied to investigations of voluntary IFRS adoption by listed firms.

Independent variables being measured in our logistic regression are summarized in Table 3. Based on the proposed hypotheses, these variables aim to measure internationality, leverage, firm size, profitability, capital intensity, industry, growth, ownership structure, employee productivity and auditors' reputation for UK unlisted firms.

$<$ Table 3>

Our choice of measures is based on the relevant literature but also on data availability which can be challenging with unlisted firms. Prior research testing of firm's international orientation generally relies on the percentage of foreign sales and total sales but this is not available for unlisted firms. We use the number of a firm's subsidiaries to represent UK unlisted firm's level of internationality. We assume that the greater the number of subsidiaries, the more it is probable that the firm is engaging in international activities.

For leverage, we use the total-debt-on-total-assets ratio and long-term-debt-on-total-assets ratio to measure the level instead of the common D/E ratio, because some unlisted firms in our sample have little equity. Firm size is measured by three variables, which are natural logarithm of operating revenues, natural logarithm of total assets and the number of employees. Three ratios are used for profitability: profit margin ratio, EBITDA margin ratio and return on total assets ratio. Similar to Dumontier and Raffournier (1998), capital intensity is measured as the percentage of fixed assets to total assets. Industry dummies divide our unlisted firms in three groups: manufacturing, financial and other. Growth is calculated in two ways: total asset growth rate and operating revenue growth rate.

While we do not have detailed information on the ownership structure of our unlisted firms, we do control for legal form. In Europe, unlisted firms are a much wider category than private firms (Nobes 2010), for example, PLCs in the UK, AGs in Germany or SAs in France, are public firms but not quoted. Two dummy variables are chosen in this paper to measure 
whether legal form affects international accounting standards choice by unlisted firms: PUB, with a value of one for public company (not quoted) and zero otherwise; and PLIMITED, with a value of one for private limited company and zero otherwise.

Finally, profits per employee and operating revenues per employee are included to assess employee productivity. Auditors' reputation is a dummy variable taking the value one if the firm employs a Big Four firm as external auditor and zero otherwise.

Given the above research variables, our general logistic regression is as follows:

$$
\begin{gathered}
V A_{i}=\alpha+\beta_{1} I_{i}+\beta_{2} L_{E V}+\beta_{3} \text { SIZE }_{i}+\beta_{4} \text { PRO }_{i}+\beta_{5} C_{i}+\beta_{6} \text { MANUF }_{i}+\beta_{7} F_{\text {FIN }}+\beta_{8} G_{\text {ROW }}+\beta_{9} \text { PUB }_{i}+ \\
\beta_{10} \text { PLIMITED }_{i}+\beta_{11} E_{i}+\beta_{12} \text { AUD }_{i}+\varepsilon_{i}
\end{gathered}
$$

Where

VA- a dummy variable with a value of one if a the unlisted firm uses IFRS in 2009 and a value of zero otherwise;

IO- international orientation, measured by the number of a firm's subsidiaries;

LEV- financial leverage ratio, which is the ratio of total debt and total assets, or the ratio of long term debt and total assets;

SIZE- firm size which is the natural logarithm of a firm's total assets or the natural logarithm of a firm's operating revenues, or the number of a firm's employees;

PRO- profitability which is a firm's profits margin ratio or EBITDA margin ratio, or ROA ratio;

$\mathrm{Cl}$ - capital intensity, measured by the ratio of fixed assets to total assets;

MANUF- industry dummy variable, with a value of one if a firm belongs to a manufacturing industry (SIC below 4000) and a value of zero otherwise;

FIN- industry dummy variable, with a value of one if a firm belongs to a financial industry and a value of zero otherwise;

GROW- rate of total assets' growth or rate of operating revenues' growth;

PUB- ownership variable, measured by a firm's legal form with a value of one for public company (not quoted) and a value of zero otherwise;

PLIMITED- ownership variable, measured by a firm's legal form with a value of one for private limited company and a value of zero otherwise;

EP- employee productivity, measured by profits per employee or operating revenues per employee;

AUD- auditors' reputation, taking value one if the auditor is a Big 4 firm and value zero otherwise;

$\varepsilon$ - the residual.

Since two or three variables are proposed to measure leverage, firm size, profitability, growth and employee productivity, we follow several steps: 
Step 1- based on univariate test results, independent variables that are significantly different between IFRS and non-IFRS groups are chosen for Logistic regression;

Step 2- based on results of step 1, replace variables with the alternative one that can also measure firm characteristics into Logistic regression, as robustness check;

Step 3- continue with more replacements to further test research hypotheses formulated in the previous section.

\section{Empirical results}

\subsection{Descriptive statistics and univariate analyses}

Descriptive statistics on all the independent variables and univariate analyses between the IFRS group and the non-IFRS group are presented separately for non-financial and financial firms. Table 4 and Table 5 present descriptive statistics respectively for non-financial firms and financial firms, comprising case number, mean, median, standard deviation, minimum and maximum of all variables for IFRS group and non-IFRS group. Table 6 and Table 7 show the results of univariate analyses, including the traditional t-test and the non-parametric test, also respectively for industrial firms and financial firms.

<Table 4, Table 5, Table 6 and Table 7>

Based on the descriptive statistics and univariate analyses, for internationality (number of subsidiaries), the IFRS group significantly differs from non-IFRS group at the 0.05 or 0.01 level for both non-financial firms and financial firms. Given that the means for IFRS and nonIFRS non-financial firms are 5 (standard deviation: 20.1581) and 1 (standard deviation: 4.6801), for IFRS and non-IFRS financial firms are 33 (standard deviation: 101.3091) and 3 (standard deviation: 9.8821), this confirms, as expected, that IFRS unlisted firms in the UK are more internationally orientated than non-IFRS firms.

As for leverage, the IFRS group significantly varies from non-IFRS group at the 0.01 level on the variable debt-total-assets ratio and long-term-debt-total-assets ratio for non-financial firms. For financial firms, only the debt-total-assets ratio is statistically significant in the nonparametric test at the 0.01 level. The means of IFRS and non-IFRS non-financial firms $(0.8486$ vs. 0.6864 for D/TA ratio; 0.2561 vs. 0.1503 for Long term debt/ TA ratio), show that IFRS unlisted non-financial firms are more leveraged than non-IFRS firms, which is consistent with our expectation. IFRS unlisted financial firms have higher debt-total-assets ratio than others while little difference on long-term-debt-total-assets ratio.

All the variables (Lg operating revenues, $\mathrm{Lg}$ total assets and number of employees) measuring firm size are statistically significant in t-test and non-parametric test at the 0.01 level for both non-financial and financial firms. In accordance with our hypothesis, larger unlisted firms in the UK are more likely to voluntarily adopt IFRS. 
There are three variables involved in this paper measuring profitability, but only EBITDA margin ratio is found to be significant in the univariate analyses for non-financial firms. The other two variables (profit margin ratio and return on total assets ratio) for non-financial firms and all three variables for financial firms fail to show significant differences between IFRS and non-IFRS groups. The results reveal that in the UK, IFRS unlisted non-financial firms have greater EBITDA margin ratio when compared with other unlisted non-financial firms, but little difference in profitability is found to affect voluntary IFRS choice for unlisted financial firms.

As regards to capital intensity, mixed results are found for non-financial and financial firms, although both of them exhibit significant differences between IFRS group and non-IFRS group in the univariate analyses. For non-financial firms, the IFRS group displays significantly higher fixed assets/TA ratio than the control group, while for financial firms, IFRS group shows significantly lower fixed assets/TA ratio. The results suggest that our research hypothesis on capital intensity applies to unlisted financial firms but not to unlisted nonfinancial firms in the UK.

The descriptive statistics and univariate analyses results fail to support the hypothesis that firms with a higher growth level are more likely to choose IFRS, either for non-financial firms or financial firms in the UK. As for ownership structure, mixed results are found for public (not quoted) firms and private limited firms. Inconsistent with our hypothesis H8, public (not quoted)UK unlisted firms, whether non-financial or financial, have a higher likelihood to voluntarily adopt IFRS than others, at a 0.01 significance level; while private limited firms have a smaller likelihood in selecting IFRS, also at a 0.01 significance level.

The employee productivity variable "operating revenues per employee" is found to be statistically significant for both non-financial and financial firms at the 0.01 level. However, the other variable "profits per employee" shows little difference between IFRS and non-IFRS groups for non-financial firms but significant difference for financial firms at the 0.05 level. The results suggest that unlisted firms with higher operating revenues per employee are more likely to use with IFRS, and unlisted financial firms with higher profits per employee have a higher likelihood of choosing IFRS. The results fail to validate our research hypothesis H9.

Finally, regarding auditor's reputation, the IFRS group significantly differs from non-IFRS group at the 0.01 level for both non-financial and financial firms. As expected, unlisted firms in the UK employing a Big 4 auditing firm are more likely to choose IFRS.

Overall, the results of the descriptive statistics and univariate analyses indicate for UK unlisted firms at the end of 2009 that IFRS non-financial firms are more internationally diversified, more leveraged, larger-sized, more likely to have a higher EBITDA margin ratio, a larger capital intensity level and higher operating revenues per employee, and also more likely to be public (not quoted) firms and employ a Big Four firm as external auditors. While 
IFRS financial firms are more internationally diversified, larger-sized, more likely to have a higher D/TA ratio, a smaller capital intensity and a higher employee productivity level, and also more likely to be public (not quoted) firms and employ a Big Four firm as external auditors.

\subsection{Multivariate analyses-Logistic regression}

Logistic regression is further performed to jointly examine research hypotheses proposed on firm characteristics. Based on discussions in the previous research model and variables section, since two or three variables are possible to measure leverage, firm size, profitability, growth and employee productivity, logistic regression estimates may be substantially biased due to probable collinearity among independent variables. Therefore, several steps are implemented:

Step 1- Based on univariate test results, independent variables that are significantly different between IFRS and non-IFRS groups are chosen for logistic regression. Thus, debt-total-assets ratio, Lg total assets, EBITDA margin ratio, growth of total assets and operating revenues per employee are selected. The Logistic regression model is formed as follows.

$$
\begin{array}{rr}
V A_{i}=\alpha+\beta_{1} I O_{i}+ & \beta_{2} L_{E V}+\beta_{3} \text { SIZE }_{i}+\beta_{4} \text { PRO }_{i}+\beta_{5} C_{i}+\beta_{6} \text { MANUF }_{\mathrm{i}}+\beta_{7} F_{N_{i}}+\beta_{8} G_{\text {GOW }}+\beta_{9} \text { PUB }_{\mathrm{i}}+ \\
\beta_{10} \text { PLIMITED }_{\mathrm{i}}+\beta_{11} \mathrm{EP}_{\mathrm{i}}+\beta_{12} \text { AUD }_{\mathrm{i}}+\varepsilon_{\mathrm{i}} & \text { (Model 1) }
\end{array}
$$

Where

VA- a dummy variable with a value of one when a firm voluntarily uses IFRS in 2009 and a value of zero otherwise;

IO- international orientation, measured by the number of a firm's subsidiaries;

LEV- financial leverage ratio which is the ratio of liabilities and total assets;

SIZE- firm size which is the natural logarithm of a firm's total assets;

PRO- profitability which is a firm's EBITDA margin ratio;

$\mathrm{Cl}$ - capital intensity, measured by the ratio of fixed assets and total assets;

MANUF- industry dummy variable, with a value of one if a firm belongs to a manufacturing industry (SIC below 4000) and a value of zero otherwise;

FIN- industry dummy variable, with a value of one if a firm belongs to a financial industry and a value of zero otherwise;

GROW- rate of total assets' growth;

PUB- ownership variable, measured by a firm's legal form with a value of one for public company (not quoted) and a value of zero otherwise;

PLIMITED- ownership variable, measured by a firm's legal form with a value of one for private limited company and a value of zero otherwise;

EP- employee productivity, measured by operating revenues per employee;

AUD- auditors' reputation, taking value one if the auditor is a Big 4 firm and value zero otherwise;

$\varepsilon$ - the residual. 
Table 8 presents the correlation matrix of the independent variables in the regression. The strongest correlations are found between PUB and PLIMITED with a correlation coefficient of 0.634, then SIZE and AUD with a correlation coefficient of -0.456 , and SIZE and $\mathrm{Cl}$ with a correlation coefficient of -0.310 . The correlations among other independent variables are more moderate, revealing that the explanatory variables respectively capture different information regarding firm's characteristics.

$<$ Table 8>

Table 9 presents the results of our logistic regression, with the Chi-Square test of model's fit at a 0.001 significance level. With combined analysis on the full sample (217 IFRS cases vs. 6535 non-IFRS cases), including non-financial and financial firms, we find that internationality, leverage, firm size and auditor's reputation display significant positive effects on UK unlisted firms' choice in selecting accounting standards, at the 0.05 or 0.01 significance level. The results are consistent with univariate analysis and support the research hypotheses $\mathrm{H} 1, \mathrm{H} 2, \mathrm{H} 3$ and $\mathrm{H} 10$, suggesting that larger unlisted firms in the UK with more international orientation, higher leverage level, employing a Big 4 firm as external auditors are more likely to comply with IFRS. While, for other firm characteristics, profitability, capital intensity, manufacturing industry, financial industry, growth, ownership structure and employee productivity, the coefficients are not significantly different from zero, suggesting that these factors do not affect the decision. Therefore, research hypotheses $\mathrm{H} 5$, $\mathrm{H} 6, \mathrm{H7}, \mathrm{H} 8$ and $\mathrm{H} 9$ are not confirmed, while research hypothesis $\mathrm{H} 4$ is validated.

\section{$<$ Table 9>}

Due to a number of missing values for the growth variable, the sample size is restricted and many IFRS and non-IFRS cases are excluded because many unlisted firms are newly incorporated. Given this, we add a dummy control variable NEW to indicate whether a firm is newly incorporated. The variable GROW is replaced with NEW in the updated regression process, as seen in Model 2.

$$
\begin{aligned}
& V A_{i}=\alpha+\beta_{1} I_{i}+\beta_{2} L_{E V}+\beta_{3} S_{I Z E_{i}}+\beta_{4} P_{R O}+\beta_{5} C l_{i}+\beta_{6} \text { MANUF }_{i}+\beta_{7} F_{I N}+\beta_{8} N W_{i}+\beta_{9} P B_{i}+ \\
& \beta_{10} \text { PLIMITED }_{i}+\beta_{11} \text { EP }_{i}+\beta_{12} \text { AUD }_{i}+\varepsilon_{i}
\end{aligned}
$$

Where

VA- a dummy variable with a value of one when a firm voluntarily adopts IFRS in 2009 and a value of zero otherwise;

IO- international orientation, measured by the number of a firm's subsidiaries;

LEV- financial leverage ratio which is the ratio of liabilities and total assets;

SIZE- firm size which is the natural logarithm of a firm's total assets;

PRO- profitability which is a firm's EBITDA margin ratio;

$\mathrm{Cl}$ - capital intensity, measured by the ratio of fixed assets and total assets; 
MANUF- industry dummy variable, with a value of one if a firm belongs to a manufacturing industry (SIC below 4000) and a value of zero otherwise;

FIN- industry dummy variable, with a value of one if a firm belongs to a financial industry and a value of zero otherwise;

NEW- incorporation variable, taking value one if a firm is incorporated after June 2008 (only one-year financial data available at the end of 2009), and a value of zero otherwise (having available financial data for more than one year);

PUB- ownership variable, measured by a firm's legal form with a value of one for public company (not quoted) and a value of zero otherwise;

PLIMITED- ownership variable, measured by a firm's legal form with a value of one for private limited company and a value of zero otherwise;

EP- employee productivity, measured by operating revenue per employee;

AUD- auditors' reputation, taking value one if the auditor is a Big 4 firm and value zero otherwise;

$\varepsilon$ - the residual.

As seen in Table 9, the sample increases to 8089 cases (251 IFRS cases vs. 7838 non-IFRS cases) compared with that in Model 1 . Model 2 reveals similar findings that internationality, leverage, firm size and auditor's reputation presents significant positive impacts on UK unlisted firms' choice in voluntarily selecting IFRS, at the 0.05 or 0.01 significance level. While other firm characteristics, profitability, capital intensity, manufacturing industry, financial industry, growth, ownership structure and employee productivity do not affect the decision in choosing IFRS by UK unlisted firms. Additionally, the control variable NEW is statistically significant in the regression process with a predicted coefficient of 0.803 , suggesting that for the UK unlisted firms, newly incorporated firms at the end of 2009 have a higher probability in complying with IFRS than others.

Overall, the multivariate analyses support the research hypotheses $\mathrm{H} 1, \mathrm{H} 2, \mathrm{H} 3, \mathrm{H} 4$ and $\mathrm{H} 10$, confirming that unlisted firms in the UK complying with IFRS are more internationally orientated, more leveraged, larger-sized, and more likely to employ a Big 4 firm as external auditors. Also newly incorporated firms are more likely to adopt IFRS. While research hypotheses $\mathrm{H} 5, \mathrm{H} 6, \mathrm{H7}, \mathrm{H} 8$ and $\mathrm{H} 9$ are not validated, revealing that other firm characteristics are found to have little effect on unlisted firms' selection of IFRS.

\section{3 Robustness checks}

\subsubsection{Alternative measures of our independent variables}

Based on discussions in the research model and variables section, we further perform step 2 and step 3 as robustness checks for multivariate analyses.

Step 2- based on results of step 1, replace variables with the alternative one that can also measure firm characteristics into Logistic regression; 
Step 3- continue with more replacements to further test research hypotheses formulated in the previous section.

$<$ Table 10>

Table 10 summarizes robustness tests. The Chi-Square tests of these models are all significant at a 0.001 level. The replacements start from profitability which fails to display significant impact on voluntary IFRS adoption by unlisted firms in Model 1. As seen in Model 1-1, EBITDA margin ratio is replaced by profit margin. The results of Model 1-1 show little difference with previous multivariate analyses results but LEV (leverage) becomes insignificant and PLIMITED (ownership variable) become significant at the 0.1 level. Similarly, in Model 1-2, EBITDA margin ratio is replaced by return on total assets ratio, and again the results show little difference; only LEV (leverage) and PLIMITED (ownership variable) become significant at the 0.1 level.

In Model 1-3, operating revenues per employee is changed with profits per. Internationality, firm size and auditor's reputation are still statistically significant, but leverage becomes insignificant when compared with results from Model 1. In Model 1-4, we use growth of operating revenues instead of growth of total assets in measuring firms' growth level, again, similarly with the previous three robustness check models, the results have little difference only making LEV (leverage) and PLIMITED (ownership variable) become significant at the 0.1 level.

Overall, leverage and ownership type of private limited are sensitive in the multivariate analyses process. When alternative independent variables are involved in the Logistic regression, leverage may become insignificant or significant and ownership type of private limited may become significant.

\subsubsection{Logistic regressions for sub-sample}

In our univariate analyses, we find different results in terms of some firm characteristics across non-financial and financial firms. We further run our logistic regressions separately for non-financial and financial samples (Model 1-5 and Model 1-6) to check the robustness of previous multivariate analyses.

As evidenced in Table 10, for the non-financial sample, the results are exactly the same as that from Model 1, IFRS non-financial unlisted firms in the UK are more internationally diversified, more leveraged, larger-sized, and more likely to employ a Big Four firm as external auditors. While for the financial sample, the results are a little bit different, besides firm size and auditor's reputation still being statistically significant at the 0.01 level, internationality becomes significant at a low level of 0.1 , leverage becomes insignificant, and capital intensity becomes significant at the 0.05 level. The results IFRS financial unlisted firms in the UK are more internationally diversified, larger-sized, more likely to have a smaller capital intensity, and also more likely to employ a Big Four firm as external auditors. 
In summary, the research hypotheses $\mathrm{H} 1, \mathrm{H} 2, \mathrm{H} 3, \mathrm{H} 4$ and $\mathrm{H} 10$ are confirmed for the nonfinancial sample, while the research hypotheses $\mathrm{H} 1, \mathrm{H} 3, \mathrm{H} 4, \mathrm{H} 5$ and $\mathrm{H} 10$ are validated for the financial sample.

\section{Conclusions}

This research is motivated by the continued debate on the costs and benefits of adopting IFRS. Proponents of IFRS claim that IFRS increases financial comparability and usefulness of accounting information (e.g. FASB 2010; IASB 2010; SEC 2008). However, other believe worldwide adoption of IFRS by all firms is costly, complex and don't necessarily improve the quality of accounting reports. As such, it is interesting to examine firms which are not obliged to use IFRS but actually voluntarily choose to report using IFRS. Given that firms are making rational decisions on the selection of a comprehensive basis of accounting presumably through weighing benefits and costs, voluntary adopters must have reasons and incentives to incur the adoption/switching costs and expect benefits. This research provides evidence of the kind of firms for whom the benefits of adopting IFRS outweigh the costs.

Academic research on financial reporting choices by unlisted firms is scarce, which may be attributed to the fact that without public disclosure requirements, financial data and accounting practices for unlisted firms are not often readily available. Research on accounting practices of unlisted firms is of great interest. Unlisted firms make up the majority of all firms in the world and IFRS adoption for unlisted firms has been hot topic debated among policy makers and standard setters in recent years. In addition, in Europe, unlisted firms are a much wider category than private firms (Nobes 2010), for example, PLCs in the UK, AGs in Germany or SAs in France, are public firms but not quoted. Thus, the results from private firms only can not extend to unlisted firms.

We examine large to medium-sized UK unlisted firms and their choice of accounting practices (IFRS or Local GAAP) in fiscal 2009. Differently from previous research on private firms, we include financial firms and subsidiaries whose parent companies are public authority/ state/ government, or families, or other types of holding firms. Our full sample of 8417 firms comprises 287 IFRS firms (3.41\%) and 8130 non-IFRS firms.

We find that for the full sample, internationality, leverage, firm size and auditor's reputation present significant positive impacts on UK unlisted firms' choice in voluntarily selecting IFRS. Other firm characteristics, profitability, capital intensity, manufacturing industry, financial industry, growth, ownership structure and employee productivity do not affect the decision in choosing IFRS by UK unlisted firms. Additionally, we find that newly incorporated have a higher probability in adopting IFRS.

This paper is one of very few examining voluntary IFRS adoption by unlisted firms. We find that unlisted firms selecting IFRS share some firm characteristics with those documented in previous research for listed firms, such as international orientation, firm size, leverage and 
auditor's reputation. The findings suggest that stronger reporting incentives also play a major role in the decision to voluntarily choose IFRS. Also, the results in this research provide empirical evidence to standard setters by indicating the type of unlisted firms which may prefer to use and benefit from IFRS.

\section{REFERENCES}

Ashbaugh, Hollis, 2001, Non-US firms' accounting standard choices, Journal of Accounting and Public Policy 20, 129-153.

Ashbaugh, Hollis, and Morton Pincus, 2001, Domestic accounting standards, international accounting standards, and the predictability of earnings, Journal of Accounting Research 39, 417-434.

Ball, Ray, S. P. Kothari, and Ashok Robin, 2000, The effect of international institutional factors on properties of accounting earnings, Journal of Accounting and Economics 29, 1-51.

Ball, Ray, Ashok Robin, and Joanna Shuang Wu, 2003, Incentives versus standards: Properties of accounting income in four east Asian countries, Journal of Accounting and Economics 36, 235-270.

Barth, Mary E., Wayne R. Landsman, and Mark H. Lang, 2008, International accounting standards and accounting quality, Journal of Accounting Research 46, 467-498.

Barth, Mary E., Wayne R. Landsman, Mark H. Lang, and Christopher D. Williams, 2011, Are international accounting standards-based and US GAAP-based accounting amounts comparable?, Rock Center for Corporate Governance at Stanford University Working Paper No. 78.

Bartov, Eli, Stephen R. Goldberg, and Myungsun Kim, 2002, Comparative value relevance among German, U.S. and international accounting standards: A German stock market perspective, Journal of Accounting Auditing and Finance, Vol. 20, No. 2, pp. 95-119, Spring.

Bassemir, Moritz, 2011, Why do private firms adopt IFRS?, Working paper. Available at SSRN: http://ssrn.com/abstract=1896283.

Beuselinck, Christof, Philip Joos, and Sofie Van der Meulen, 2007, International earnings comparability, Working paper, Tilburg University.

Bowen, Robert M., Larry DuCharme, and D. J. Shores, 1999, Economic and industry determinants of accounting method choice, Working paper, Foster School of Business, University of Washington.

Brochet, Francois, Alan D. Jagolinzer, and Edward J. Riedl, 2011, Mandatory IFRS adoption and financial statement comparability, Harvard Business School Working Paper No. 1819482.

Cascino, Stefano, and Joachim Gassen, 2010, Mandatory IFRS adoption and accounting comparability, Humboldt University, Collaborative Research Center, Discussion paper 649.

Christensen, Hans B., Edward Lee, and Martin Walker, 2008, Incentives or standards: What determines accounting quality changes around IFRS adoption?, AAA 2008 Financial Accounting and Reporting Section (FARS).

Coppens, Laurent, and Erik Peek, 2005, An analysis of earnings management by European private firms, Journal of International Accounting, Auditing and Taxation 14, 1-17.

Covrig, Vicentiu, Mark DeFond, and Mingyi Hung, 2007, Home bias, foreign mutual fund holdings, and the voluntary adoption of international accounting standards, Journal of Accounting Research 45, 41-70.

Cuijpers, Rick, and Willem Buijink, 2005, Voluntary adoption of non-local GAAP in the European union: A study of determinants and consequences, European Accounting Review 14, 487-524.

Daske, Holger, 2006, Economic benefits of adopting IFRS or US-GAAP - have the expected cost of equity capital really decreased?, Journal of Business Finance \& Accounting 33, 329-373. 
Daske, Holger, Luzi Hail, Christian Leuz, and Rodrigo S. Verdi, 2011, Adopting a label: Heterogeneity in the economic consequences of ifrs adoptions, Working paper (SSRN).

DeFond, Mark, Xuesong Hu, Mingyi Hung, and Siqi Li, 2011, The impact of mandatory IFRS adoption on foreign mutual fund ownership: The role of comparability, Journal of Accounting and Economics 51, 240-258.

Drake, Michael S., Linda A. Myers, and Lijie Yao, 2010, Are liquidity improvements around the mandatory adoption of IFRS attributable to comparability effects or to quality effects?, AAA 2010 Financial Accounting and Reporting Section (FARS).

Dumontier, Pascal, and Bernard Raffournier, 1998, Why firms comply voluntarily with IAS: An empirical analysis with Swiss data, Journal of International Financial Management \& Accounting 9, 216-245.

Durocher, Sylvain, and Yves Gendron, 2011, IFRS: On the docility of sophisticated users in preserving the ideal of comparability, European Accounting Review, 20 (2), 233-262.

El-Gazzar, Samir M., Philip M. Finn, and Rudy Jacob, 1999, An empirical investigation of multinational firms' compliance with international accounting standards, The International Journal of Accounting 34, 239-248.

FASB, 2010, Conceptual framework for financial reporting, (Financial Accounting Standards Board).

Francis, Jere R., Inder K. Khurana, Xiumin Martin, and Raynolde Pereira, 2008, The role of firmspecific incentives and country factors in explaining voluntary IAS adoptions: Evidence from private firms, European Accounting Review 17, 331-360.

Güenther, Nina, Bernhard Gegenfurtner, Christoph Kaserer, Ann-Kristin Achleitner, 2009, International financial reporting standards and earnings quality: The myth of voluntary vs. mandatory adoption. CEFS Working Paper No. 2009-09.

Gassen, Joachim, and Thorsten Sellhorn, 2006, Applying IFRS in Germany: Determinants and consequences, working paper, Humboldt University of Berlin, WHU Otto Beisheim School of Management.

Hail, Luzi, Christian Leuz, and Peter Wysocki, 2010, Global accounting convergence and the potential adoption of IFRS by the U.S. (part I): Conceptual underpinnings and economic analysis, Accounting Horizons 24, 355-394 2010b.

Hail, Luzi, Christian Leuz, and Peter Wysocki, 2010, Global accounting convergence and the potential adoption of IFRS by the U.S. (part II): Political factors and future scenarios for U.S. Accounting standards, Accounting Horizons 24, 567-588 2010a.

Hung, Mingyi, and K. R. Subramanyam, 2007, Financial statement effects of adopting international accounting standards: the case of Germany, Review of Accounting Studies 12, 623-657.

IASB, 2010, Conceptual framework for financial reporting, (International Accounting Standards Board).

Jamal, Karim, Robert H. Colson, Robert J. Bloomfield, Theodore E. Christensen, Stephen R. Moehrle, James A. Ohlson, Stephen H. Penman, Gary J. Previts, Thomas L. Stober, Shyam Sunder, and Ross L. Watts, 2010, A research based perspective on SEC's proposed rule on roadmap for potential use of financial statements prepared in accordance with international financial reporting standards (IFRS) by U.S. Issuers, Accounting Horizons 24, 139-147.

Karamanou, Irene, and George P. Nishiotis, 2009, Disclosure and the cost of capital: Evidence from the market's reaction to firm voluntary adoption of IAS, Journal of Business Finance \& Accounting 36, 793-821.

Kim, Jeong-Bon, Judy Tsui, and Cheong Yi, 2011, The voluntary adoption of international financial reporting standards and loan contracting around the world, Review of Accounting Studies 133.

Kvaal, Erlend, and Christopher W. Nobes, 2010, International differences in IFRS policy choice, Accounting and Business Research, Forthcoming. 
Lang, Mark H., Mark G. Maffett, and Edward L. Owens 2010, Earnings comovement and accounting comparability: The effects of mandatory IFRS adoption, Simon School Working Paper No. FR 11-03.

Leuz, Christian, and Robert E. Verrecchia, 2000, The economic consequences of increased disclosure, Journal of Accounting Research 38, 91-124.

Leuz, Christian, and Peter D Wysocki, 2008, Economic consequences of financial reporting and disclosure regulation: A review and suggestions for future research. University of Chicago and MIT working paper.

Maddala, G.S., 1991, A perspective on the use of limited-dependent and qualitative variables models in accounting research. The Accounting Review 66, 788-807.

Murphy, Ann B., 1999, Firm characteristics of Swiss companies that utilize international accounting standards, The International Journal of Accounting 34, 121-131.

Nobes, C., 2010, On researching into the use of IFRS by private entities in Europe, Accounting in Europe 7, 213-226.

Paananen, Mari, and Henghsiu Lin, 2009, The development of accounting quality of IAS and IFRS over time: The case of Germany, Journal of International Accounting Research 8, 31-55.

Palepu, K.G., 1986, Predicting takeover targets: A methodological and empirical analysis. Journal of Accounting and Economics 8, 3-35.

Peek, Erik, Rick Cuijpers, and Willem Buijink, 2010, Creditors' and shareholders' reporting demands in public versus private firms: Evidence from Europe, Contemporary Accounting Research 27, 49-91.

Raffournier, Bernard, 1995, The determinants of voluntary financial disclosure by Swiss listed companies, European Accounting Review 4, 261-280.

Schipper, Katherine, 2005, The introduction of international accounting standards in Europe: Implications for international convergence, European Accounting Review 14, 101-126.

SEC, 2008, Roadmap for the potential use of financial statements prepared in accordance with international financial reporting standards by US issuers., (Securities and Exchange Commission, Washington DC).

Soderstrom, Naomi S., and Jialin Sun, 2007, IFRS adoption and accounting quality: A review, European Accounting Review 16, 675-702.

Street, Donna L., and Sidney J. Gray, 2002, Factors influencing the extent of corporate compliance with international accounting standards: Summary of a research monograph, Journal of International Accounting, Auditing and Taxation 11, 51-76.

Tarca, Ann, 2004, International convergence of accounting practices: Choosing between IAS and US GAAP, Journal of International Financial Management \& Accounting 15, 60-91.

Touron, Philippe, 2005, The adoption of US GAAP by French firms before the creation of the International Accounting Standard Committee: An institutional explanation, Critical Perspectives on Accounting 16, 851-873.

Tweedie, David, 2010, IFRS in 2011 and beyond, 2010 International Financial Reporting Standards (IFRSs) Conference (Tokyo).

Van Tendeloo, Brenda, and Ann Vanstraelen, 2005, Earnings management under German GAAP versus IFRS, European Accounting Review 14, 155-180.

Weißenberger, Barbara E., Anne B. Stahl, and Sven Vorstius, 2004, Changing from German GAAP to IFRS or US GAAP: A survey of German companies, Accounting in Europe 1, 169-189.

Wu, Joanna S., and Ivy Zhang, 2010, Accounting integration and comparability: Evidence from relative performance evaluation around IFRS adoption, Simon School Working Paper No. FR 10-25.

Wu, Shuang Joanna, and Ivy Xiying Zhang, 2009a, The adoption of internationally recognized accounting standards: Implications for the credit markets, SSRN working paper (SSRN).

Wu, Shuang Joanna, and Ivy Xiying Zhang, 2009b, The voluntary adoption of internationally recognized accounting standards and firm internal performance evaluation, Accounting Review 84, 1281-1309. 
Zeff, Stephen A., 2007, Some obstacles to global financial reporting comparability and convergence at a high level of quality, The British Accounting Review 39, 290-302. 
Table 1 Literature review on firm characteristics of voluntary IFRS adoption

\begin{tabular}{|c|c|c|c|c|c|}
\hline \multirow{2}{*}{$\begin{array}{c}\text { Firm } \\
\text { characteristics }\end{array}$} & \multirow{2}{*}{$\begin{array}{l}\text { Number } \\
\text { of sets of } \\
\text { results }\end{array}$} & \multicolumn{3}{|c|}{ Number of significant results } & \multirow[b]{2}{*}{ Study that confirm } \\
\hline & & Positive & Negative & $\begin{array}{c}\text { Not } \\
\text { significant }\end{array}$ & \\
\hline $\begin{array}{l}\text { Internationally } \\
\text { oriented }\end{array}$ & 9 & 9 & 0 & 0 & $\begin{array}{l}\text { Dumontier and Raffournier, } \\
\text { 1998; Murphy, 1999; El-Gazzar } \\
\text { et al., 1999; Tarca 2004; Cuijpers } \\
\text { and Buijink, 2005; Gassen and } \\
\text { Sellhorn, 2006; Francis et al., } \\
\text { 2008; Wu and Zhang, 2009; } \\
\text { Bassemir 2011 }\end{array}$ \\
\hline Cross-listed & 8 & 8 & 0 & 0 & $\begin{array}{l}\text { Dumontier and Raffournier, } \\
\text { 1998; Murphy, 1999; El-Gazzar } \\
\text { et al., 1999; Ashbaugh 2001; } \\
\text { Tarca 2004; Cuijpers and Buijink, } \\
\text { 2005; Gassen and Sellhorn, } \\
\text { 2006; Wu and Zhang, } 2009\end{array}$ \\
\hline $\begin{array}{l}\text { Capital } \\
\text { structure/ } \\
\text { Leverage }\end{array}$ & 8 & 2 & 1 & 5 & $\begin{array}{c}\text { Dumontier and Raffournier, } \\
\text { 1998; Murphy, 1999; El-Gazzar } \\
\text { et al., 1999; Tarca 2004; Cuijpers } \\
\text { and Buijink, 2005; Gassen and } \\
\text { Sellhorn, 2006; Wu and Zhang, } \\
\text { 2009; Bassemir } 2011\end{array}$ \\
\hline Size & 8 & 7 & 0 & 1 & $\begin{array}{l}\text { Dumontier and Raffournier, } \\
\text { 1998; Murphy, 1999; Tarca } \\
\text { 2004; Cuijpers and Buijink, 2005; } \\
\text { Gassen and Sellhorn, 2006; } \\
\text { Francis et al., 2008; Wu and } \\
\text { Zhang, 2009; Bassemir } 2011 \\
\end{array}$ \\
\hline $\begin{array}{l}\text { Ownership } \\
\text { concentration/ } \\
\text { type }\end{array}$ & 7 & $1^{9}$ & 5 & 1 & $\begin{array}{l}\text { Dumontier and Raffournier, } \\
\text { 1998; Cuijpers and Buijink, 2005; } \\
\text { Gassen and Sellhorn, 2006; } \\
\text { Francis et al., 2008; Wu and } \\
\text { Zhang, 2009; Guenther et al., } \\
\text { 2009; Bassemir } 2011\end{array}$ \\
\hline Country & 4 & 4 & 0 & 0 & $\begin{array}{l}\text { Ashbaugh 2001; Tarca 2004; } \\
\text { Cuijpers and Buijink, 2005; } \\
\text { Francis et al., } 2008\end{array}$ \\
\hline Industry & 3 & 2 & 0 & 1 & $\begin{array}{l}\text { Tarca 2004; Cuijpers and Buijink, } \\
\text { 2005; Gassen and Sellhorn, } 2006\end{array}$ \\
\hline $\begin{array}{l}\text { Auditors' } \\
\text { reputation }\end{array}$ & 3 & 1 & 0 & 2 & $\begin{array}{c}\text { Dumontier and Raffournier, } \\
\text { 1998; Murphy, 1999; Bassemir } \\
2011\end{array}$ \\
\hline Profitability & 3 & 0 & 0 & 3 & $\begin{array}{c}\text { Dumontier and Raffournier, } \\
\text { 1998; Wu and Zhang, 2009; } \\
\text { Bassemir } 2011\end{array}$ \\
\hline
\end{tabular}

\footnotetext{
${ }^{9}$ The result from Bassemir (2011) indicates positive association of voluntary IFRS adoption with ownership type.
} 


\begin{tabular}{|c|c|c|c|c|c|}
\hline \multirow{2}{*}{$\begin{array}{c}\text { Firm } \\
\text { characteristics }\end{array}$} & $\begin{array}{c}\text { Number } \\
\text { of sets of } \\
\text { results }\end{array}$ & \multicolumn{2}{|c|}{ Number of significant results } & \multirow{2}{*}{ Study that confirm } \\
\cline { 5 - 6 } $\begin{array}{c}\text { Anticipation of } \\
\text { stock }\end{array}$ & 3 & 3 & 0 & 0 & $\begin{array}{c}\text { Not } \\
\text { Ashbaugh 2001; Gassen and } \\
\text { issuance/ IPOs }\end{array}$ \\
\hline sellhorn, 2006; Bassemir 2011
\end{tabular}


Table 2 Research sample collection

\begin{tabular}{|c|c|r|r|r|}
\hline \multicolumn{2}{|c|}{ Sample } & IFRS sample & Control sample & $\begin{array}{c}\text { The percentage of } \\
\text { IFRS sample }\end{array}$ \\
\hline \multirow{3}{*}{$\begin{array}{c}\text { UK unlisted } \\
\text { firms }\end{array}$} & Industry firms & 216 & 7285 & $2.88 \%$ \\
\cline { 2 - 5 } & Financial firms & 71 & 845 & $7.75 \%$ \\
\cline { 2 - 5 } & Total & 287 & 8130 & $3.41 \%$ \\
\hline
\end{tabular}

Selection criterions used in Orbis database: 1) UK active and unlisted firms; 2) firms using IFRS in their 2009 financial statements; 3) large or medium-sized firms according to the criteria of the Fourth EU Company Law Directive; 4) independent firms and subsidiaries whose parent companies are public authority/state/government, or families, or other types of private holding firms. 
Table 3 Measurements of variables of firm characteristics

\begin{tabular}{|c|c|}
\hline $\begin{array}{c}\text { Firm } \\
\text { characteristics }\end{array}$ & Measurements \\
\hline Internationality & $\mathrm{IO}=$ the number of firm's subsidiaries \\
\hline $\begin{array}{l}\text { Capital structure/ } \\
\text { Leverage }\end{array}$ & $\begin{array}{l}\text { LEV1= D/ TA, total debt/ total assets } \\
\text { LEV2= long term debt/ total assets }\end{array}$ \\
\hline Size & $\begin{array}{l}\text { SIZE1= natural logarithm of firm's operating revenues } \\
\text { SIZE 2= natural logarithm of firm's total assets } \\
\text { SIZE 3= the number of firm's employees }\end{array}$ \\
\hline Profitability & $\begin{array}{l}\text { PRO1= Profit margin ratio, (net profit / revenue) } \times 100 \\
\text { PRO2= EBITDA margin ratio, (earnings before interest, taxes, depreciation, and } \\
\text { amortization) / revenue } \times 100 \\
\text { PRO3= ROA, return on total assets }\end{array}$ \\
\hline Capital intensity & $\mathrm{Cl}=$ fixed assets $/$ total assets \\
\hline Industry & $\begin{array}{l}\text { MANUF= } 1 \text { if a firm belongs to a manufacturing industry (SIC below 4000), and } 0 \\
\text { otherwise } \\
\text { FIN = } 1 \text { if a firm belongs to a financial industry, and } 0 \text { otherwise }\end{array}$ \\
\hline Growth & $\begin{array}{l}\text { GROW1 }=\text { total assets' growth rate, }\left(\text { total assets } \mathrm{t}_{\mathrm{t}} \text { - total assets } \mathrm{t}_{\mathrm{t}-1} \text { )/ total assets } \mathrm{t}_{\mathrm{t}}\right. \\
\text { GROW2 } \text { operating revenues' growth rate, (operating revenues } \mathrm{t}_{\mathrm{t}} \text { - operating } \\
\text { revenues } \mathrm{t}_{\mathrm{t}-1} \text { )/ operating revenues } \mathrm{t}_{\mathrm{t}}\end{array}$ \\
\hline $\begin{array}{l}\text { Ownership } \\
\text { structure }\end{array}$ & $\begin{array}{l}\text { PUB = a firm's legal form, } 1 \text { for public company (not quoted) and } 0 \text { otherwise } \\
\text { PLIMITED= a firm's legal form, } 1 \text { for private limited company and } 0 \text { otherwise }\end{array}$ \\
\hline $\begin{array}{l}\text { Employee } \\
\text { productivity }\end{array}$ & $\begin{array}{l}\text { EP1= profits per employee, profits/ the number of employees } \\
\text { EP2= operating revenues per employee, operating revenues/ the number of } \\
\text { employees }\end{array}$ \\
\hline $\begin{array}{l}\text { Auditors' } \\
\text { reputation }\end{array}$ & $A U D=1$ if the auditor is a Big 4 firm, and 0 otherwise \\
\hline
\end{tabular}


Table 4 Descriptive Statistics for UK non-financial firms-- IFRS group versus non-IFRS group

\begin{tabular}{|c|c|c|c|c|c|c|c|c|c|c|c|c|}
\hline \multirow{2}{*}{ Variables } & & & & & & & & & & & Unit: th & and Euros \\
\hline & $\mathrm{N}$ & Mean & Median & St. D & Min & Max & $\mathrm{N}$ & Mean & Median & St. D & Min & Max \\
\hline $\begin{array}{l}\text { Number of } \\
\text { subsidiaries }\end{array}$ & 216 & 5 & 1 & 20.1581 & 0 & 281 & 7285 & 1 & 0 & 4.6801 & 0 & 235 \\
\hline \multicolumn{13}{|l|}{ Leverage: } \\
\hline $\begin{array}{l}\text { Long term } \\
\text { debt/ Total } \\
\text { assets (TA) }\end{array}$ & 193 & 0.2561 & 0.0954 & 0.3263 & 0.0000 & 1.3784 & 6210 & 0.1503 & 0.0507 & 0.2739 & 0.0000 & 6.5258 \\
\hline \multicolumn{13}{|l|}{ Size: } \\
\hline $\begin{array}{l}\text { Lg Operating } \\
\text { revenues }\end{array}$ & 216 & 4.9117 & 4.8358 & 0.7202 & 3.7231 & 7.1487 & 7285 & 4.3015 & 4.2023 & 0.4420 & 3.6992 & 8.1426 \\
\hline $\begin{array}{l}\text { Number of } \\
\text { employees }\end{array}$ & 216 & 3381 & 332 & 16071.214 & 50 & 185602 & 7285 & 337 & 122 & 2274.908 & 50 & 171483 \\
\hline \multicolumn{13}{|l|}{ Profitability: } \\
\hline $\begin{array}{l}\text { Profit margin } \\
\text { ratio }\end{array}$ & 208 & 2.9699 & 2.6800 & 20.6968 & -90.5800 & 85.9700 & 7207 & 3.3885 & 2.5400 & 11.6689 & -99.3000 & 90.7500 \\
\hline $\begin{array}{c}\text { EBITDA } \\
\text { margin ratio }\end{array}$ & 202 & 11.6097 & 9.4900 & 21.0561 & -67.4600 & 97.8700 & 7164 & 7.4149 & 5.5600 & 11.8536 & -97.1100 & 89.5100 \\
\hline
\end{tabular}




\begin{tabular}{|c|c|c|c|c|c|c|c|c|c|c|c|c|}
\hline \multirow{2}{*}{ Variables } & \multicolumn{6}{|c|}{ IFRS firms } & \multicolumn{6}{|c|}{ Non-IFRS firms } \\
\hline & $\mathrm{N}$ & Mean & Median & St. D & Min & Max & $\mathrm{N}$ & Mean & Median & St. D & Min & Max \\
\hline ROA & 212 & 4.5577 & 3.6600 & 21.9069 & -96.4700 & 84.7300 & 7200 & 5.6660 & 4.6150 & 14.7011 & -95.1400 & 99.5200 \\
\hline \multicolumn{13}{|c|}{ Capital intensity: } \\
\hline $\begin{array}{l}\text { Fixed assets/ } \\
\text { Total assets }\end{array}$ & 216 & 0.4717 & 0.4643 & 0.3094 & 0.0000 & 0.9806 & 7285 & 0.3592 & 0.3103 & 0.2698 & -0.1874 & 0.9927 \\
\hline \multicolumn{13}{|l|}{ Growth: } \\
\hline Growth of TA & 185 & 0.0827 & 0.0234 & 0.4681 & -0.7766 & 3.7563 & 6320 & 0.0959 & 0.0170 & 1.8141 & -0.9186 & 100.5806 \\
\hline $\begin{array}{l}\text { Growth of } \\
\text { Operating } \\
\text { revenues }\end{array}$ & 181 & 0.1183 & -0.0066 & 0.7162 & -0.6733 & 7.2595 & 4451 & 0.0577 & -0.0003 & 0.8522 & -0.9529 & 34.6801 \\
\hline \multicolumn{13}{|l|}{ Ownership: } \\
\hline Public firms & 216 & 0.0600 & 0 & 0.2471 & 0 & 1 & 7285 & 0.0300 & 0 & 0.1781 & 0 & 1 \\
\hline $\begin{array}{c}\text { Private } \\
\text { limited firms }\end{array}$ & 216 & 0.8000 & 1 & 0.4001 & 0 & 1 & 7285 & 0.9000 & 1 & 0.3041 & 0 & 1 \\
\hline \multicolumn{13}{|c|}{ Employee productivity: } \\
\hline $\begin{array}{l}\text { Profits per } \\
\text { employee }\end{array}$ & 207 & 21.1791 & 5.1328 & 88.8393 & -67.6540 & 1000.5686 & 7175 & 8.9979 & 3.4030 & 47.8823 & -74.0920 & 2150.4671 \\
\hline $\begin{array}{l}\text { Operating } \\
\text { revenues per } \\
\text { employee }\end{array}$ & 216 & 268.2352 & 165.4058 & 401.6910 & 4.5515 & 3768.1126 & 7284 & 201.4462 & 124.2869 & 686.0189 & 2.7960 & 50486.9212 \\
\hline \multicolumn{13}{|l|}{ Auditor: } \\
\hline Big Four & 216 & 0.6800 & 1 & 0.4671 & 0 & 1 & 7268 & 0.2500 & 0 & 0.4301 & 0 & 1 \\
\hline
\end{tabular}


Table 5 Descriptive Statistics for UK financial firms-- IFRS group versus non-IFRS group

\begin{tabular}{|c|c|c|c|c|c|c|c|c|c|c|c|c|}
\hline \multirow{2}{*}{ Variables } & \multicolumn{6}{|c|}{ IFRS firms } & \multicolumn{6}{|c|}{ Non-IFRS firms } \\
\hline & $\mathrm{N}$ & Mean & Median & St. D & Min & Max & $\mathrm{N}$ & Mean & Median & St. D & Min & Max \\
\hline \multicolumn{13}{|l|}{ Internationality: } \\
\hline $\begin{array}{l}\text { Number of } \\
\text { subsidiaries }\end{array}$ & 71 & 33 & 3 & 101.3091 & 0 & 542 & 845 & 3 & 1 & 9.8821 & 0 & 225 \\
\hline \multicolumn{13}{|l|}{ Leverage: } \\
\hline $\mathrm{D} / \mathrm{TA}$ & 71 & 0.8858 & 0.8956 & 0.2989 & 0.1130 & 1.8859 & 836 & 0.8577 & 0.7553 & 0.7431 & 0.0657 & 13.1329 \\
\hline $\begin{array}{l}\text { Long term } \\
\text { debt/ Total } \\
\text { assets (TA) }\end{array}$ & 44 & 0.2673 & 0.0485 & 0.3242 & 0.0000 & 0.9017 & 753 & 0.2734 & 0.1221 & 0.3623 & 0.0000 & 2.0551 \\
\hline \multicolumn{13}{|l|}{ Size: } \\
\hline $\begin{array}{l}\text { Lg Operating } \\
\text { revenues }\end{array}$ & 71 & 5.0353 & 5.0552 & 0.7417 & 3.8954 & 7.2566 & 845 & 4.3867 & 4.2668 & 0.5553 & 3.6990 & 7.2745 \\
\hline Lg Total assets & 71 & 5.5582 & 5.5989 & 0.9943 & 3.5155 & 8.3984 & 845 & 4.4299 & 4.2199 & 0.7403 & 3.3985 & 7.0381 \\
\hline $\begin{array}{l}\text { Number of } \\
\text { employees }\end{array}$ & 71 & 2850 & 443 & 7761.480 & 60 & 47938 & 845 & 541 & 133 & 1620.913 & 50 & 18760 \\
\hline \multicolumn{13}{|l|}{ Profitability: } \\
\hline $\begin{array}{l}\text { Profit margin } \\
\text { ratio }\end{array}$ & 68 & 2.6594 & 6.2650 & 27.1436 & -80.8600 & 56.7000 & 830 & 1.2041 & 1.5650 & 19.3547 & -88.8900 & 91.2800 \\
\hline $\begin{array}{c}\text { EBITDA } \\
\text { margin ratio }\end{array}$ & 49 & 13.9173 & 9.5300 & 23.7262 & -29.6600 & 85.4900 & 802 & 9.5067 & 6.6800 & 17.1045 & -71.0600 & 90.9300 \\
\hline ROA & 64 & -0.0587 & 0.2650 & 14.4877 & -55.6100 & 31.8200 & 833 & 2.2605 & 1.5500 & 15.5528 & -97.5200 & 88.4600 \\
\hline
\end{tabular}




\begin{tabular}{|c|c|c|c|c|c|c|c|c|c|c|c|c|}
\hline \multirow{2}{*}{ Variables } & \multicolumn{6}{|c|}{ IFRS firms } & \multicolumn{6}{|c|}{ Non-IFRS firms } \\
\hline & $\mathrm{N}$ & Mean & Median & St. D & Min & Max & $\mathrm{N}$ & Mean & Median & St. D & Min & Max \\
\hline \multicolumn{13}{|c|}{ Capital intensity: } \\
\hline $\begin{array}{l}\text { Fixed assets/ } \\
\text { Total assets }\end{array}$ & 65 & 0.3572 & 0.2619 & 0.3508 & 0.0000 & 0.9489 & 836 & 0.4564 & 0.4559 & 0.3077 & -0.0032 & 0.9872 \\
\hline \multicolumn{13}{|l|}{ Growth: } \\
\hline Growth of TA & 63 & 0.0483 & 0.0281 & 0.3311 & -0.6313 & 1.2901 & 474 & 0.0516 & 0.0044 & 0.3412 & -0.8060 & 2.1973 \\
\hline $\begin{array}{l}\text { Growth of } \\
\text { Operating } \\
\text { revenues }\end{array}$ & 61 & -0.1246 & -0.0292 & 1.5071 & -9.7449 & 4.3875 & 438 & 0.3232 & 0.0325 & 3.8712 & -0.9286 & 78.7047 \\
\hline \multicolumn{13}{|l|}{ Ownership: } \\
\hline Public firms & 71 & 0.1700 & 0 & 0.3771 & 0 & 1 & 845 & 0.0300 & 0 & 0.1661 & 0 & 1 \\
\hline $\begin{array}{l}\text { Private limited } \\
\text { firms }\end{array}$ & 71 & 0.6900 & 1 & 0.4661 & 0 & 1 & 845 & 0.8700 & 1 & 0.3371 & 0 & 1 \\
\hline \multicolumn{13}{|c|}{ Employee productivity: } \\
\hline $\begin{array}{l}\text { Profits per } \\
\text { employee }\end{array}$ & 58 & 48.0429 & 12.8251 & 123.2640 & -51.7471 & 753.5418 & 812 & 15.9675 & 2.1085 & 100.7337 & -69.8487 & 1597.4921 \\
\hline $\begin{array}{l}\text { Operating } \\
\text { revenues per } \\
\text { employee }\end{array}$ & 71 & 325.5276 & 166.9382 & 438.0353 & 10.6364 & 2340.1108 & 844 & 248.9981 & 116.0352 & 859.0050 & 2.6152 & 17167.4249 \\
\hline \multicolumn{13}{|l|}{ Auditor: } \\
\hline Big Four & 71 & 0.7600 & 1 & 0.4321 & 0 & 1 & 837 & 0.3300 & 0 & 0.4692 & 0 & 1 \\
\hline
\end{tabular}


Table 6 Univariate analyses for UK non-financial firms-- IFRS group versus non-IFRS group

\begin{tabular}{|c|c|c|c|c|c|}
\hline \multirow{2}{*}{$\begin{array}{c}\text { Firm } \\
\text { characteristics }\end{array}$} & \multirow{2}{*}{ Variables } & \multicolumn{2}{|c|}{ T test } & \multicolumn{2}{|c|}{$\begin{array}{l}\text { Non-parametric test } \\
\text { (Mann-Whitney test) }\end{array}$} \\
\hline & & t value & $\begin{array}{c}\text { Sig. } \\
\text { (2-tailed) }\end{array}$ & $Z$ value & Sig. \\
\hline Internationality & Number of subsidiaries & -2.259 & $0.025^{* *}$ & -6.864 & $0.000 * * *$ \\
\hline \multirow{2}{*}{ Leverage } & $\mathrm{D} / \mathrm{TA}$ & -4.659 & $0.000^{* * *}$ & -6.561 & $0.000 * * *$ \\
\hline & Long term debt/ Total assets & -4.455 & $0.000 * * *$ & -2.776 & $0.005^{* * *}$ \\
\hline \multirow{3}{*}{ Size } & Lg Operating revenues & -12.382 & $0.000^{* * *}$ & -13.233 & $0.000 * * *$ \\
\hline & Lg Total assets & -14.545 & $0.000 * * *$ & -15.677 & $0.000 * * *$ \\
\hline & Number of employees & -2.783 & $0.006 * * *$ & -10.730 & $0.000 * * *$ \\
\hline \multirow{3}{*}{ Profitability } & Profit margin ratio & 0.290 & 0.772 & -0.818 & 0.413 \\
\hline & EBITDA margin ratio & -2.819 & $0.005^{* * *}$ & -4.314 & $0.000 * * *$ \\
\hline & Return on total assets & 0.732 & 0.465 & -1.755 & $0.079 *$ \\
\hline Capital intensity & Fixed assets/ Total assets & -5.286 & $0.000 * * *$ & -5.189 & $0.000 * * *$ \\
\hline \multirow[b]{2}{*}{ Growth } & Growth of TA & 0.099 & 0.921 & -0.303 & 0.762 \\
\hline & $\begin{array}{l}\text { Growth of operating } \\
\text { revenues }\end{array}$ & -0.943 & 0.346 & -0.288 & 0.773 \\
\hline \multirow{2}{*}{ Ownership } & Public firms & 1.892 & $0.060 *$ & -2.568 & $0.010 * * *$ \\
\hline & Private firms & -3.510 & $0.001^{* * *}$ & -4.546 & $0.000 * * *$ \\
\hline \multirow{2}{*}{$\begin{array}{l}\text { Employee } \\
\text { productivity }\end{array}$} & Profits per employee & -1.965 & $0.051 *$ & -1.437 & 0.151 \\
\hline & $\begin{array}{c}\text { Operating revenues per } \\
\text { employee }\end{array}$ & -1.424 & 0.155 & -4.826 & $0.000 * * *$ \\
\hline Auditor & Big four & -13.518 & $0.000 * * *$ & -14.408 & $0.000 * * *$ \\
\hline
\end{tabular}

Significance level: $* 10 \%, * * 5 \%, * * * 1 \%$ 
Table 7 Univariate analyses for UK financial firms-- IFRS group versus non-IFRS group

\begin{tabular}{|c|c|c|c|c|c|}
\hline \multirow{2}{*}{$\begin{array}{c}\text { Firm } \\
\text { characteristics }\end{array}$} & \multirow{2}{*}{ Variables } & \multicolumn{2}{|c|}{ T test } & \multicolumn{2}{|c|}{$\begin{array}{l}\text { Non-parametric test } \\
\text { (Mann-Whitney test) }\end{array}$} \\
\hline & & t value & $\begin{array}{c}\text { Sig. } \\
\text { (2-tailed) }\end{array}$ & Z value & Sig. \\
\hline Internationality & Number of subsidiaries & -2.490 & $0.015^{* *}$ & -4.221 & $0.000 * * *$ \\
\hline \multirow{2}{*}{ Leverage } & $\mathrm{D} / \mathrm{TA}$ & -0.640 & 0.523 & -3.251 & $0.001 * * *$ \\
\hline & Long term debt/ Total assets & 0.109 & 0.913 & -0.303 & 0.762 \\
\hline \multirow{3}{*}{ Size } & Lg Operating revenues & -7.201 & $0.000 * * *$ & -7.564 & $0.000 * * *$ \\
\hline & Lg Total assets & -9.346 & $0.000 * * *$ & -9.013 & $0.000 * * *$ \\
\hline & Number of employees & -2.502 & $0.015^{* *}$ & -6.154 & $0.000 * * *$ \\
\hline \multirow{3}{*}{ Profitability } & Profit margin ratio & -0.433 & 0.666 & -1.349 & 0.177 \\
\hline & EBITDA margin ratio & -1.281 & 0.206 & -1.046 & 0.296 \\
\hline & Return on total assets & 1.155 & 0.248 & -0.945 & 0.344 \\
\hline Capital intensity & Fixed assets/ Total assets & 2.214 & $0.030^{* *}$ & -2.827 & $0.005^{* * *}$ \\
\hline \multirow[b]{2}{*}{ Growth } & Growth of TA & 0.074 & 0.941 & -0.610 & 0.542 \\
\hline & $\begin{array}{l}\text { Growth of operating } \\
\text { revenues }\end{array}$ & 0.893 & 0.372 & -0.889 & 0.374 \\
\hline \multirow{2}{*}{ Ownership } & Public firms & 3.114 & $0.003 * * *$ & -5.853 & $0.000 * * *$ \\
\hline & Private firms & -3.182 & $0.002 * * *$ & -4.138 & $0.000 * * *$ \\
\hline \multirow{2}{*}{$\begin{array}{l}\text { Employee } \\
\text { productivity }\end{array}$} & Profits per employee & -1.936 & $0.057^{*}$ & -2.505 & $0.012 * *$ \\
\hline & $\begin{array}{c}\text { Operating revenues per } \\
\text { employee }\end{array}$ & -0.742 & 0.458 & -2.737 & $0.006 * * *$ \\
\hline Auditor & Big four & -7.965 & $0.000 * * *$ & -7.215 & $0.000 * * *$ \\
\hline
\end{tabular}

Significance level: $* 10 \%, * * 5 \%, * * * 1 \%$ 
Table 8 Correlation matrix of independent variables

\begin{tabular}{|c|c|c|c|c|c|c|c|c|c|c|c|c|}
\hline & 10 & LEV & SIZE & PRO & $\mathrm{Cl}$ & MANUF & FIN & GROW & PUB & PLIMITED & EP & AUD \\
\hline 10 & 1.000 & & & & & & & & & & & \\
\hline LEV & 0.032 & 1.000 & & & & & & & & & & \\
\hline SIZE & -0.089 & 0.004 & 1.000 & & & & & & & & & \\
\hline PRO & -0.054 & 0.165 & -0.176 & 1.000 & & & & & & & & \\
\hline $\mathrm{Cl}$ & 0.113 & -0.045 & -0.310 & -0.143 & 1.000 & & & & & & & \\
\hline MANUF & 0.024 & 0.046 & 0.017 & 0.055 & 0.095 & 1.000 & & & & & & \\
\hline FIN & -0.073 & -0.092 & -0.185 & -0.016 & -0.039 & 0.198 & 1.000 & & & & & \\
\hline GROW & 0.001 & -0.001 & 0.005 & -0.001 & 0.002 & 0.000 & 0.001 & 1.000 & & & & \\
\hline PUB & -0.019 & 0.092 & -0.078 & 0.087 & 0.014 & -0.090 & 0.016 & 0.000 & 1.000 & & & \\
\hline PLIMITED & 0.011 & 0.103 & -0.012 & 0.088 & -0.012 & -0.128 & 0.019 & -0.002 & 0.634 & 1.000 & & \\
\hline EP & 0.012 & 0.018 & -0.096 & -0.028 & 0.136 & 0.007 & -0.117 & 0.001 & 0.005 & -0.011 & 1.000 & \\
\hline AUD & 0.033 & -0.123 & -0.456 & -0.020 & 0.123 & 0.019 & 0.031 & 0.001 & -0.044 & -0.111 & -0.010 & 1.000 \\
\hline
\end{tabular}


Table 9 Output results of Logistic regressions

\begin{tabular}{|c|c|c|c|c|c|}
\hline \multirow{2}{*}{\multicolumn{2}{|c|}{ Independent variables }} & \multicolumn{2}{|c|}{ Model 1} & \multicolumn{2}{|c|}{ Model 2} \\
\hline & & Coefficients & Sig & Coefficients & Sig \\
\hline 10 & Number of subsidiaries & 0.010 & $0.004^{* * *}$ & 0.010 & $0.003 * * *$ \\
\hline LEV & $\mathrm{D} / \mathrm{TA}$ & 0.241 & $0.044 * *$ & 0.250 & $0.027^{* *}$ \\
\hline SIZE & Lg TA & 1.300 & $0.000^{* * *}$ & 1.303 & $0.000 * * *$ \\
\hline PRO & EBITDA margin ratio & 0.000 & 0.912 & -0.002 & 0.581 \\
\hline $\mathrm{Cl}$ & Fixed assets/ TA & 0.101 & 0.700 & 0.017 & 0.945 \\
\hline MANUF & Dummy variable & -0.171 & 0.359 & -0.140 & 0.422 \\
\hline FIN & Dummy variable & 0.015 & 0.944 & -0.156 & 0.419 \\
\hline GROW & Growth of TA & 0.000 & 0.888 & & \\
\hline PUB & Dummy variable & 0.040 & 0.919 & 0.159 & 0.665 \\
\hline PLIMITED & Dummy variable & -0.362 & 0.179 & -0.288 & 0.255 \\
\hline EP & $\begin{array}{c}\text { Operating revenues per } \\
\text { employee }\end{array}$ & 0.000 & 0.675 & 0.000 & 0.566 \\
\hline AUD & Dummy variable & 0.853 & $0.000 * * *$ & 0.891 & $0.000 * * *$ \\
\hline NEW & Dummy variable & & & 0.803 & $0.004 * * *$ \\
\hline
\end{tabular}

Chi-Square Test of Model's Fit (Sig.): 0.000 (Model 1, 2)

Model 1 cases: 6752 (IFRS cases: 217 vs. Non-IFRS cases: 6535)

Model 2 cases: 8089 (IFRS cases: 251 vs. Non-IFRS cases: 7838)

Significance level: *10\%, **5\%, ***1\%

Where

IO- international orientation, measured by the number of a firm's subsidiaries;

LEV- financial leverage ratio which is the ratio of liabilities and total assets;

SIZE- firm size which is the natural logarithm of a firm's total assets;

PRO- profitability which is a firm's EBITDA margin ratio;

$\mathrm{Cl}$ - capital intensity, measured by the ratio of fixed assets and total assets;

MANUF- industry dummy variable, with a value of one if a firm belongs to a manufacturing industry (SIC below 4000) and a value of zero otherwise;

FIN- industry dummy variable, with a value of one if a firm belongs to a financial industry and a value of zero otherwise;

GROW- rate of total assets' growth;

PUB- ownership variable, measured by a firm's legal form with a value of one for public company (not quoted) and a value of zero otherwise;

PLIMITED- ownership variable, measured by a firm's legal form with a value of one for private limited company and a value of zero otherwise;

EP- employee productivity, measured by operating revenues per employee;

AUD- auditors' reputation, taking value one if the auditor is a Big 4 firm and value zero otherwise;

NEW- incorporation variable, taking value one if a firm is incorporated after June 2008 (only one-year financial data available at the end of 2009), and a value of zero otherwise (having available financial data for more than one year) 
Table 10 Robustness tests results

\begin{tabular}{|c|c|c|c|c|c|c|c|}
\hline \multirow{2}{*}{\multicolumn{2}{|c|}{ Independent variables }} & \multirow{2}{*}{$\begin{array}{c}\text { Model 1-1 } \\
\text { Coefficients } \\
\text { (sig.) }\end{array}$} & \multirow{2}{*}{$\begin{array}{l}\text { Model 1-2 } \\
\text { Coefficients } \\
\text { (sig.) }\end{array}$} & \multirow{2}{*}{$\begin{array}{c}\text { Model 1-3 } \\
\text { Coefficients } \\
\text { (sig.) }\end{array}$} & \multirow{2}{*}{$\begin{array}{l}\text { Model 1-4 } \\
\text { Coefficients } \\
\text { (sig.) }\end{array}$} & \multirow{2}{*}{$\begin{array}{c}\text { Model 1-5 } \\
\text { Coefficients } \\
\text { (sig.) }\end{array}$} & \multirow{2}{*}{$\begin{array}{c}\text { Model 1-6 } \\
\text { Coefficients } \\
\text { (sig.) }\end{array}$} \\
\hline & & & & & & & \\
\hline 10 & Number of subsidiaries & $\begin{array}{r}0.009 \\
\left(0.005^{* * *}\right)\end{array}$ & $\begin{array}{r}0.009 \\
\left(0.005^{* * *}\right)\end{array}$ & $\begin{array}{r}0.010 \\
\left(0.004^{* * *}\right)\end{array}$ & $\begin{array}{r}0.009 \\
\left(0.005^{* * *}\right)\end{array}$ & $\begin{array}{r}0.002 \\
\left(0.008^{* * *}\right)\end{array}$ & $\begin{array}{r}0.012 \\
\left(0.064^{*}\right)\end{array}$ \\
\hline LEV & $\mathrm{D} / \mathrm{TA}$ & $\begin{array}{r}0.119 \\
(0.332) \\
\end{array}$ & $\begin{array}{r}0.178 \\
(0.099 *) \\
\end{array}$ & $\begin{array}{r}0.156 \\
(0.314) \\
\end{array}$ & $\begin{array}{r}0.209 \\
\left(0.093^{*}\right) \\
\end{array}$ & $\begin{array}{r}0.264 \\
\left(0.035^{* *}\right) \\
\end{array}$ & $\begin{array}{r}0.174 \\
(0.481) \\
\end{array}$ \\
\hline SIZE & $\operatorname{Lg} T A$ & $\begin{array}{r}1.335 \\
(0.000 * * *) \\
\end{array}$ & $\begin{array}{r}1.337 \\
(0.000 * * *) \\
\end{array}$ & $\begin{array}{r}1.308 \\
(0.000 * * *) \\
\end{array}$ & $\begin{array}{r}1.206 \\
(0.000 * * *) \\
\end{array}$ & $\begin{array}{r}1.378 \\
(0.000 * * *) \\
\end{array}$ & $\begin{array}{r}1.236 \\
\left(0.000^{* * *}\right) \\
\end{array}$ \\
\hline \multirow{3}{*}{ PRO } & EBITDA margin ratio & & & $\begin{array}{r}-0.007 \\
(0.198) \\
\end{array}$ & $\begin{array}{r}0.000 \\
(0.988) \\
\end{array}$ & $\begin{array}{r}-0.002 \\
(0.661) \\
\end{array}$ & $\begin{array}{r}0.001 \\
(0.908) \\
\end{array}$ \\
\hline & Profit margin ratio & $\begin{array}{r}0.000 \\
(0.989) \\
\end{array}$ & & & & & \\
\hline & ROA & & $\begin{array}{r}0.000 \\
(0.978) \\
\end{array}$ & & & & \\
\hline $\mathrm{Cl}$ & Fixed assets/ TA & $\begin{array}{r}-0.170 \\
(0.500)\end{array}$ & $\begin{array}{r}-0.146 \\
(0.562)\end{array}$ & $\begin{array}{r}0.290 \\
(0.279)\end{array}$ & $\begin{array}{r}0.124 \\
(0.641)\end{array}$ & $\begin{array}{r}0.465 \\
(0.114)\end{array}$ & $\begin{array}{r}-1.268 \\
\left(0.033^{* *}\right)\end{array}$ \\
\hline MANUF & Dummy variable & $\begin{array}{r}-0.221 \\
(0.233) \\
\end{array}$ & $\begin{array}{r}-0.209 \\
(0.257) \\
\end{array}$ & $\begin{array}{r}-0.202 \\
(0.287) \\
\end{array}$ & $\begin{array}{r}-0.178 \\
(0.343) \\
\end{array}$ & & \\
\hline FIN & Dummy variable & $\begin{array}{r}0.202 \\
(0.305)\end{array}$ & $\begin{array}{r}0.141 \\
(0.471)\end{array}$ & $\begin{array}{r}0.062 \\
(0.778)\end{array}$ & $\begin{array}{r}-0.038 \\
(0.856)\end{array}$ & & \\
\hline \multirow{2}{*}{ GROW } & Growth of TA & $\begin{array}{r}0.000 \\
(0.879) \\
\end{array}$ & $\begin{array}{r}0.000 \\
(0.887)\end{array}$ & $\begin{array}{r}0.000 \\
(0.890)\end{array}$ & & $\begin{array}{r}0.000 \\
(0.891)\end{array}$ & $\begin{array}{r}-0.036 \\
(0.952)\end{array}$ \\
\hline & $\begin{array}{c}\text { Growth of operating } \\
\text { revenues }\end{array}$ & & & & $\begin{array}{r}-0.010 \\
(0.834) \\
\end{array}$ & & \\
\hline PUB & Dummy variable & $\begin{array}{r}0.209 \\
(0.548)\end{array}$ & $\begin{array}{r}0.222 \\
(0.525)\end{array}$ & $\begin{array}{r}0.005 \\
(0.989)\end{array}$ & $\begin{array}{r}-0.200 \\
(0.614)\end{array}$ & $\begin{array}{r}0.190 \\
(0.613)\end{array}$ & $\begin{array}{r}0.007 \\
(0.889) \\
\end{array}$ \\
\hline PLIMITED & Dummy variable & $\begin{array}{r}-0.457 \\
\left(0.068^{*}\right) \\
\end{array}$ & $\begin{array}{r}-0.455 \\
\left(0.074^{*}\right) \\
\end{array}$ & $\begin{array}{r}-0.408 \\
(0.138) \\
\end{array}$ & $\begin{array}{r}-0.527 \\
\left(0.067^{*}\right) \\
\end{array}$ & $\begin{array}{r}-0.324 \\
(0.182) \\
\end{array}$ & $\begin{array}{r}-0.514 \\
(0.123) \\
\end{array}$ \\
\hline
\end{tabular}




\begin{tabular}{|c|c|c|c|c|c|c|c|}
\hline \multirow{2}{*}{\multicolumn{2}{|c|}{ Independent variables }} & Model 1-1 & Model 1-2 & Model 1-3 & Model 1-4 & Model 1-5 & Model 1-6 \\
\hline & & $\begin{array}{l}\text { Coefficients } \\
\text { (sig.) }\end{array}$ & $\begin{array}{l}\text { Coefficients } \\
\text { (sig.) }\end{array}$ & $\begin{array}{l}\text { Coefficients } \\
\text { (sig.) }\end{array}$ & $\begin{array}{l}\text { Coefficients } \\
\text { (sig.) }\end{array}$ & $\begin{array}{l}\text { Coefficients } \\
\text { (sig.) }\end{array}$ & $\begin{array}{l}\text { Coefficients } \\
\text { (sig.) }\end{array}$ \\
\hline \multirow{2}{*}{ EP } & $\begin{array}{c}\text { Operating revenues per } \\
\text { employee }\end{array}$ & $\begin{array}{r}0.000 \\
(0.741) \\
\end{array}$ & $\begin{array}{r}0.000 \\
(0.682) \\
\end{array}$ & & $\begin{array}{r}0.000 \\
(0.739) \\
\end{array}$ & $\begin{array}{r}0.000 \\
(0.401) \\
\end{array}$ & $\begin{array}{r}0.000 \\
(0.425) \\
\end{array}$ \\
\hline & Profits per employee & & & $\begin{array}{r}0.001 \\
(0.404)\end{array}$ & & & \\
\hline AUD & Dummy variable & $\begin{array}{r}0.821 \\
\left(0.000^{* * *}\right)\end{array}$ & $\begin{array}{r}0.781 \\
(0.000 * * *)\end{array}$ & $\begin{array}{r}0.883 \\
(0.000 * * *)\end{array}$ & $\begin{array}{r}0.694 \\
(0.000 * * *)\end{array}$ & $\begin{array}{r}0.939 \\
\left(0.000^{* * *}\right)\end{array}$ & $\begin{array}{r}0.909 \\
\left(0.004^{* * *}\right) \\
\end{array}$ \\
\hline
\end{tabular}

Chi-Square Test of Model's Fit (Sig.): 0.000 (Model 1-1, 1-2, 1-3, 1-4, 1-5, 1-6)

Model 1-1 cases: 6828 (IFRS cases: 235 vs. Non-IFRS cases: 6593);

Model 1-2 cases: 6833 (IFRS cases: 239 vs. Non-IFRS cases: 6594);

Model 1-3 cases: 6737 (IFRS cases: 208 vs. Non-IFRS cases: 6529);

Model 1-4 cases: 4868 (IFRS cases: 213 vs. Non-IFRS cases: 4655);

Model 1-5 cases: 6377 (IFRS cases: 175 vs. Non-IFRS cases: 6202);

Model 1-6 cases: 494 (IFRS cases: 44 vs. Non-IFRS cases: 450 ).

Significance level: $* 10 \%, * * 5 \%, * * * 1 \%$

Where

IO- international orientation, measured by the number of a firm's subsidiaries;

LEV- financial leverage ratio which is the ratio of liabilities and total assets;

SIZE- firm size which is the natural logarithm of a firm's total assets;

PRO- profitability which is a firm's EBITDA margin ratio (or profit margin ratio, or ROA);

$\mathrm{Cl}$ - capital intensity, measured by the ratio of fixed assets and total assets;

MANUF- industry dummy variable, with a value of one if a firm belongs to a manufacturing industry (SIC below 4000$)$ and a value of zero otherwise;

FIN- industry dummy variable, with a value of one if a firm belongs to a financial industry and a value of zero otherwise;

GROW- rate of total assets' growth (or rate of operating revenues' growth);

PUB- ownership variable, measured by a firm's legal form with a value of one for public company (not quoted) and a value of zero otherwise;

PLIMITED- ownership variable, measured by a firm's legal form with a value of one for private limited company and a value of zero otherwise;

EP- employee productivity, measured by operating revenues per employee (or total assets per employee);

AUD- auditors' reputation, taking value one if the auditor is a Big 4 firm and value zero otherwise; 